\title{
Modelling inter- and intra-regional tourism flows in Spain - a spatial econometric approach
}

Marcos Álvarez-Díaz

European Commission, Joint Research Centre

E-mail:

marcos.alvarez@ec.europa.eu

Beatrice D'Hombres

European Commission, Joint Research Centre

E-mail:

Beatrice.DHOMBRES@ec.europa.eu

Claudia Ghisetti

European Commission, Joint Research Centre

E-mail:

Claudia.GHISETTI@ec.europa.eu
Domestic tourism is one of the most important types of tourism in Spain, but also one of the most neglected and underresearched. The objective of this study is to 1. describe the domestic tourist flows in Spain for the year 2016 and 2. shed some light on the factors that drive this form of tourism. To describe domestic tourism, a destination-origin matrix is constructed, and the coefficients of tourist attraction for each region are calculated. The analysis of the driving factors is based on the estimation of a gravity model and a spatial autoregressive (SAR) model. The SAR model has the advantage of accounting for spatial interactions' effects among regions. The authors' empirical findings reveal that spatial regional dependence matters when modelling domestic tourist flows. Moreover, the level of income at both the origin and destination regions, and the characteristics of the region of destination, such as the quality of beaches, level of accessibility, and the number of museums, theme parks and natural parks are also positively associated with domestic tourism. On the contrary, distance and relative prices between the regions of origin and destination exert a negative effect. The estimates of the SAR model allow the quantification of the total, direct and spillo-

Keywords: ver effects of these factors. According to domestic tourism, this quantification, it is found that the despatial autoregressive model, mand for inter-regional domestic tourism is elasticities, unitary income elastic and highly price elasSpain tic. 


\section{Introduction}

It is widely recognised that tourism is a key strategic sector for the economic, social, and cultural development of many countries (UNWTO 2010, Medina-Muñoz et al. 2016). This is particularly the case for Spain, with tourism being one of its most important and fastest growing economic sectors. The significant relevance of tourism for Spain is reflected in the latest outlook of the Spanish travel and tourism sector released by the World Travel and Tourism Council (WTTC 2017). According to this report, the total contribution of the sector to the Spanish economy was 158.9 billion euros in 2016 ( $14.2 \%$ of the gross domestic product [GDP]), and is expected to rise by $3.8 \%$ in 2017 . This growth rate is significantly above the one foreseen by the European Commission for the global Spanish economy in 2017 $(2.8 \%)$. The importance of the tourism sector in the Spanish economy has grown since 2010. Essentially, the sector has played a determinant role in reducing the negative impact of the economic crisis over the past years, and is currently one of the drivers of economic recovery (Cuadrado-Roura-López-Morales 2014, LaCaixa 2017). The travel and tourism industry employed approximately $14.5 \%$ of the labour force (2.6 million of jobs) in 2016. More than 80,000 new jobs have been created in the sector in 2016, which represents $15.1 \%$ of all jobs generated over the same period in Spain (Exceltur 2017). The unemployment rate in Spain is, after Greece, the highest in the European Union (EU) (18.5\% in 2016), and more than twice the average rate registered in the EU area. According to the information contained in the surveys conducted by the Spanish Sociological Research Centre, the high level of unemployment has been recurrently perceived in the last ten years as the most important problem that the Spanish population is facing. Tourism is viewed by the Spanish political authorities as a strategic sector to promote growth, create new jobs, and consequently, reduce the high rate of unemployment.

Spanish policy-makers have designed and implemented different policies in the last few years to promote research, development, and innovation (R\&D\&I) activities, both in the academia and in the tourism sector. For instance, the Spanish Tourism Plan Horizon 2020 as well as the National Science and Technology Strategy 2013-2020 aimed at improving the competitiveness of the sector through, in particular, R\&D\&I activities that could be used by the tourism sector and would contribute to increase productivity and employment in the short- and medium-terms.

Most of the existing research on tourism in Spain has so far focused on explaining international tourist inbounds (see references included in Álvarez-Díaz et al. 2016). The economic importance that international tourism has for the Spanish economy explains the scientific interest for this topic. ${ }^{1}$ Most of these studies rely on time series or panel data and show that income of those who travel and the adjusted

${ }^{1}$ According to Bankia (2016), Spain received 75.3 million foreign visitors in 2016 and obtained revenues of more than 77.6 billion euros.

Regional Statistics, Vol. 7. No. 2. 2017: 3-34; DOI: 10.15196/RS070205 
relative prices are the main determinants of international tourism. ${ }^{2}$ The estimated elasticities provided by researchers are essential for policy-makers and tourism managers to understand how changes in income and relative prices affect the international demand for tourism to Spain.

In contrast, the domestic demand for tourism has not been significantly studied despite the fact that it represents a substantial portion of total tourism activities in Spain (INE 2017). In 2016, the total expenditure of domestic flows amounted to 28.15 billion euros (INE 2017). Guardia-Gálvez et al. (2014) discuss this lack of evidence and emphasise the need to stimulate more research on the underlying determinants of domestic tourism. A better understanding of the domestic tourism flows would complement the existing knowledge on international tourism, and help national and regional governments to design and implement more effective tourism policies.

To the best of our knowledge, only two recent studies have modelled the domestic demand for tourism in Spain. Guardia-Gálvez et al. (2014) employ a gravity model to characterise the explanatory variables that determine the domestic travel flows between the Spanish regions. Their results suggest that the population of the regions, at both origin and destination, and the income of the origin region have a positive and significant influence on domestic tourism in Spain. The estimated income elasticity is greater than one, which suggests that domestic demand for tourism is a luxury good. On the other hand, the distance between regions exerts a negative effect. Other factors such as relative prices and the characteristic of insularity are not significantly associated with the tourism flows. In the second study, De la Mata and Llano-Verduras (2012) use different specifications of the gravity model to explain the intra- and interregional trade flows of the accommodation, restaurant, and travel agency sectors. The results show that some socio-economic and geographic characteristics (such as temperature, beach, and capital of the state) of the destination regions are important pull factors for domestic tourism. The variable distance is also included, and shows a significant and negative effect. In one of the gravity modelling specifications, the authors control for spatial autocorrelation. As the presence of spatial autocorrelation is not conclusive, the authors recommend undertaking further research on this issue by using alternative modelling specifications. ${ }^{3}$

The present study attempts to contribute to the limited literature on the determinants of domestic flows in Spain. The objectives of the study are twofold. The first one is to provide a detailed description of the tourist flows between and within the Spanish regions (inter-regional and intra-regional tourism, respectively) for the year 2016. In order to consider both inter- and intra-regional tourism, an

\footnotetext{
2 Other determinants such as relative prices in substitute destinations (tourist competitors) and special events (terrorist attacks, changes in visa policy, and the Arab Spring) have also been found relevant to explain the international tourism demand for Spain (Álvarez-Díaz et al. 2016).

${ }^{3}$ The authors affirm that the presence of spatial dependence to explain tourist flows is not conclusive as they find a positive and significant effect in 2001, but no effect in 2007.
}

Regional Statistics, Vol. 7. No. 2. 2017: 3-34; DOI: 10.15196/RS070205 
origin-destination (O-D) matrix is constructed based on the surveys conducted by the Spanish National Statistics Institute (INE). This matrix reflects the number of tourist trips from one Spanish region to another (inter-regional tourism), and to the same region (intra-regional tourism). Based on the O-D matrix, pairwise coefficients of regional tourist attractions are calculated. These coefficients are useful to identify the favourite destinations for the residents in each Spanish region.

The second objective of the paper is to model the domestic flows in Spain and study what the main determinants of inter-regional and intra-regional flows are. In particular, the main interest of this study is to provide to policy-makers and tourism managers the estimates of the income and price elasticity of demand for domestic tourism in Spain. The econometric approach is based on the O-D econometric models explained in LeSage and Pace (2008). More precisely, a SAR model and a gravity model are specified, estimated, and compared. Whilst the gravity model is the most commonly used model in the literature, the SAR model accounts for the presence of spillover effects in tourism (i.e. the existence of spatial interaction effects among regions). That is, it takes into account the fact that tourism demand in one specific region could benefit from the tourism demand experienced in neighbouring regions. Spillover effects are rather common in tourism. Yang and Wong (2012) define this concept in the context of tourism research as the indirect or unintentional effects that a region's tourism exerts on tourism flows to other regions. ${ }^{4}$ Griffith and Jones (1980) is one of the first studies to discuss these spatial spillover effects in the literature. Since then, only a few studies have included spatial spillover effects when modelling the domestic demand for tourism (among them are the aforementioned study of De la Mata and Llano-Verduras (2012) for Spain, Marrocu and Paci (2013) for Italy, and Bo et al. (2017) and Yang and Wong (2012) and Yang and Fik (2014) for China). In totality, the literature has so far not reached a consensus on the significance of spatial spillover effects in tourism (Bo et al. 2017). Drawing on this, the originality of the current work is thus not only to shed more light on the determinants of domestic tourism, but also to provide empirical evidence on the presence/absence of spatial spillover effects in tourism in Spain by exploiting an SAR model.

The remainder of this study is structured as follows. Chapter 2 provides a brief description of the domestic tourism in Spain, distinguishing between inter-regional and intra-regional flows. The coefficients of tourist attractions are shown and commented. Chapter 3 describes the SAR and gravity models (the latter used as a benchmark), as well as the variables used in this study. Chapter 4 presents the main results and the discussion. Chapter 5 provides a sensitivity analysis of our results to different modelling specifications, and finally, Chapter 6 offers some conclusions and political implications.

\footnotetext{
${ }^{4}$ These authors explain several reasons why tourism flows to one geographic region are dependent on flows to other regions (e.g. productivity spillovers, market access spillovers, joint promotion, negative events, and from the demand side, the existence of tourists with multi-destination travel plans).
}

Regional Statistics, Vol. 7. No. 2. 2017: 3-34; DOI: 10.15196/RS070205 


\section{Description of the domestic inter-regional and intra-regional flows}

\section{Description of the total domestic tourist flows}

The purpose of this chapter is to characterise the flows of domestic tourism in Spain. Spain is administratively and politically decentralised into 17 regions (called autonomous communities) and 2 autonomous cities (Ceuta and Melilla). Therefore, the total number of regions considered in this study is $n=19$. Figures $2 \mathrm{a}$ and $2 \mathrm{~b}$ show the names and geographical localisations of each of these regions.

To study the Spanish regional flows, an O-D matrix is constructed. This matrix is based on the household panel survey FAMILITUR, which is regularly conducted by the INE. The matrix is derived from the 2016 survey and provides information about the bilateral tourism flows from the $n$ regions of origin to each one of the $n$ regions of destination. In other words, it registers the number of trips made by the residents in one specific region to another region or to their own region. The matrix is square and its size is $n$ rows by $n$ columns, where the rows represent the regions of destination and the columns are the regions of origin. The diagonal elements of the matrix represent the intra-regional flows, while the off-diagonal elements register the inter-regional flows.

According to the O-D matrix and the information provided by the INE database, the residents in Spain made 182 million trips in 2016, 91.4\% of which had Spain as the main destination (domestic tourism). ${ }^{5}$ Travelling by car is the most common mode of transport for domestic tourism (approximately $82.4 \%$ of the total domestic trips). The average expenses per person and day is estimated to be $44 \mathrm{eu}-$ ros. This amount is noticeably lower than what is spent in the context of trips abroad (96 euros per person and day). Most of the residents lodged in non-market accommodations $\left(63.9 \%\right.$ of domestic trips). ${ }^{6}$

Table 1 shows the distribution of domestic tourist trips (inbound and outbound trips) across the Spanish regions for the year 2016. The regions are ranked twice, based on the percentage of inbound and outbound trips, respectively. Regarding the inbound trips, the top five regions account for $61.1 \%$ of the total domestic inbound trips. The most visited region is Andalusia (Andalucía) (19.11\%), followed by Catalonia (Cataluña) (13.47\%), Valencia (10.34\%), Castilla-León (10.33\%), and Madrid $(7.85 \%)$. On the other hand, the least visited destinations are the autonomous cities of Melilla $(0.02 \%)$ and Ceuta $(0.03 \%)$, and the region of La Rioja $(1.43 \%)$. It is interesting to note the low percentage of domestic tourism to Balearic Islands (Islas Baleares) (3.24\%). This archipelago, similar to Canary Islands (Islas Canarias), is

\footnotetext{
${ }^{5}$ The O-D information is not included, but it is available upon request. The information provided by the INE can be consulted on the webpage www.ine.es

${ }^{6}$ The non-market accommodation refers to accommodations at housing properties, timeshare lodges, or at friends' and relatives' homes.
}

Regional Statistics, Vol. 7. No. 2. 2017: 3-34; DOI: 10.15196/RS070205 
focused more on international tourism than on domestic tourism. On an average, for domestic trips to Canary Islands, Madrid, and Balearic Islands, the amount spent by a person and per day is twice what is spent when the trip destination is CastillaLa Mancha, Castilla-León, and Extremadura.

Ranking of Spanish regions by the number of

Table 1 regional domestic tourist trips, 2016

\begin{tabular}{|c|c|c|c|c|c|c|}
\hline & $\begin{array}{c}\text { Region } \\
\text { of destination }\end{array}$ & $\begin{array}{c}\text { Number of } \\
\text { inbound trips, } \\
\text { million }\end{array}$ & $\begin{array}{l}\text { Share in } \\
\text { total, } \%\end{array}$ & $\begin{array}{l}\text { Region } \\
\text { of origin }\end{array}$ & $\begin{array}{l}\text { Number of } \\
\text { outbound } \\
\text { trips, million }\end{array}$ & $\begin{array}{l}\text { Share in } \\
\text { total, \% }\end{array}$ \\
\hline 1 & Andalusia & 31.76 & 19.11 & Madrid & 31.22 & 18.79 \\
\hline 2 & Catalonia & 22.39 & 13.47 & Andalusia & 26.95 & 16.21 \\
\hline 3 & Valencia & 17.18 & 10.34 & Catalonia & 24.84 & 14.95 \\
\hline 4 & Castilla-León & 17.17 & 10.33 & Valencia & 14.24 & 8.57 \\
\hline 5 & Madrid & 13.04 & 7.85 & Castilla-León & 10.61 & 6.38 \\
\hline 6 & Castilla-La Mancha & 12.18 & 7.32 & País Vasco & 9.45 & 5.68 \\
\hline 7 & Galicia & 9.72 & 5.84 & Galicia & 8.50 & 5.11 \\
\hline 8 & Aragon & 8.01 & 4.82 & Castilla-La Mancha & 7.82 & 4.71 \\
\hline 9 & Canary Islands & 5.71 & 3.44 & Aragon & 6.33 & 3.81 \\
\hline 10 & País Vasco & 4.86 & 2.92 & Canary Islands & 5.28 & 3.18 \\
\hline 11 & Extremadura & 4.76 & 2.86 & Asturias & 4.05 & 2.44 \\
\hline 12 & Cantabria & 4.17 & 2.51 & Murcia & 3.96 & 2.38 \\
\hline 13 & Asturias & 4.17 & 2.51 & Extremadura & 3.82 & 2.30 \\
\hline 14 & Murcia & 3.76 & 2.26 & Navarra & 3.01 & 1.81 \\
\hline 15 & Balearic Islands & 3.24 & 1.95 & Balearic Islands & 2.51 & 1.51 \\
\hline 16 & Navarra & 2.59 & 1.56 & Cantabria & 2.05 & 1.24 \\
\hline 17 & La Rioja & 1.43 & 0.86 & La Rioja & 1.15 & 0.69 \\
\hline 18 & Ceuta & 0.04 & 0.03 & Ceuta & 0.27 & 0.16 \\
\hline 19 & Melilla & 0.04 & 0.02 & Melilla & 0.16 & 0.10 \\
\hline
\end{tabular}

Note: Here and hereinafter, the word 'regions' refers to the 17 regions and 2 autonomous cities of Spain. Deviations from $100.00 \%$ result from rounding.

Source: Own calculation based on the O-D matrix constructed from the 2016 FAMILITUR survey.

With regard to the domestic outbound flows, most of the trips were made by the residents of Madrid (18.79\%), Andalusia (16.21\%), and Catalonia (14.95\%). The residents of Ceuta $(0.16 \%)$, Melilla $(0.10 \%)$, and Cantabria $(0.69 \%)$ show the lowest inclination to travel. The residents of Balearic Islands, Canary Islands, and Cantabria spend more than 60 euros per day and person, whilst those from Andalusia, País Vasco, Aragon (Aragón), and Murcia spend marginally less than 50 euros per day and person.

Regional Statistics, Vol. 7. No. 2. 2017: 3-34; DOI: 10.15196/RS070205 
Modelling inter- and intra-regional tourism flows in Spain - a spatial econometric approach

Figure 1a Number and distribution of regional domestic tourist trips by regions of origin (outbound trips), 2016

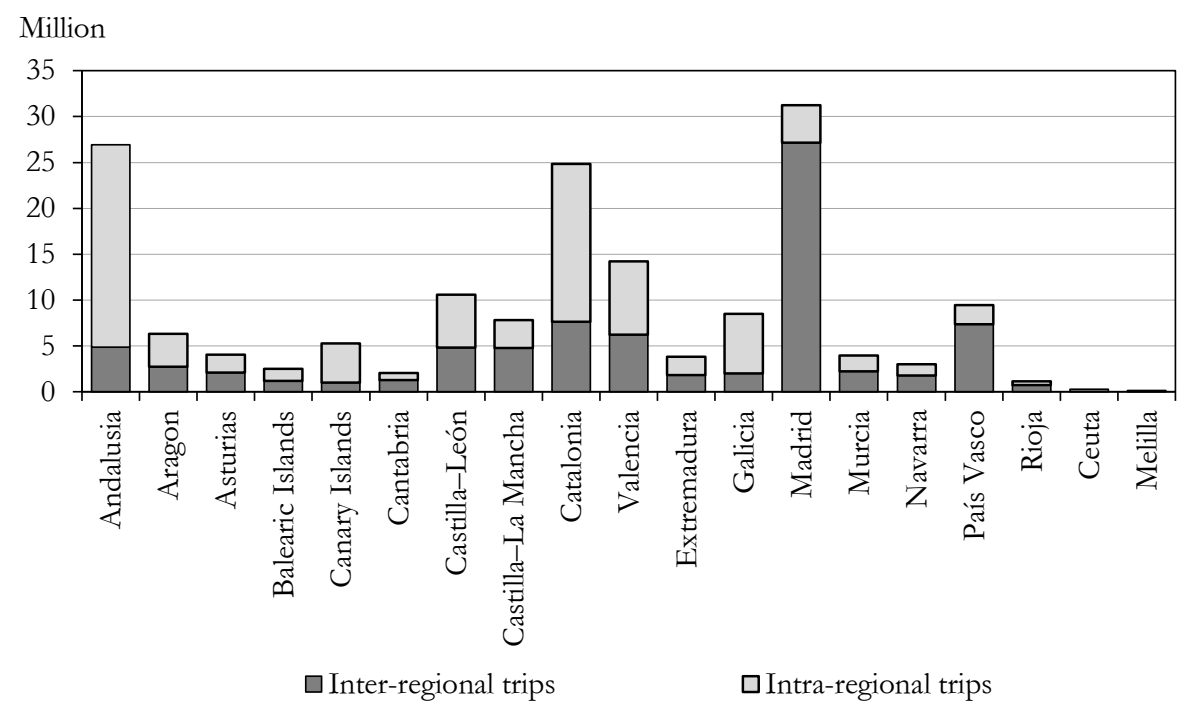

Source: Own elaboration based on the O-D matrix derived from the 2016 FAMILITUR survey.

Figure $1 \mathrm{~b}$

Number and distribution of regional domestic tourist trips by regions of destination (inbound trips), 2016

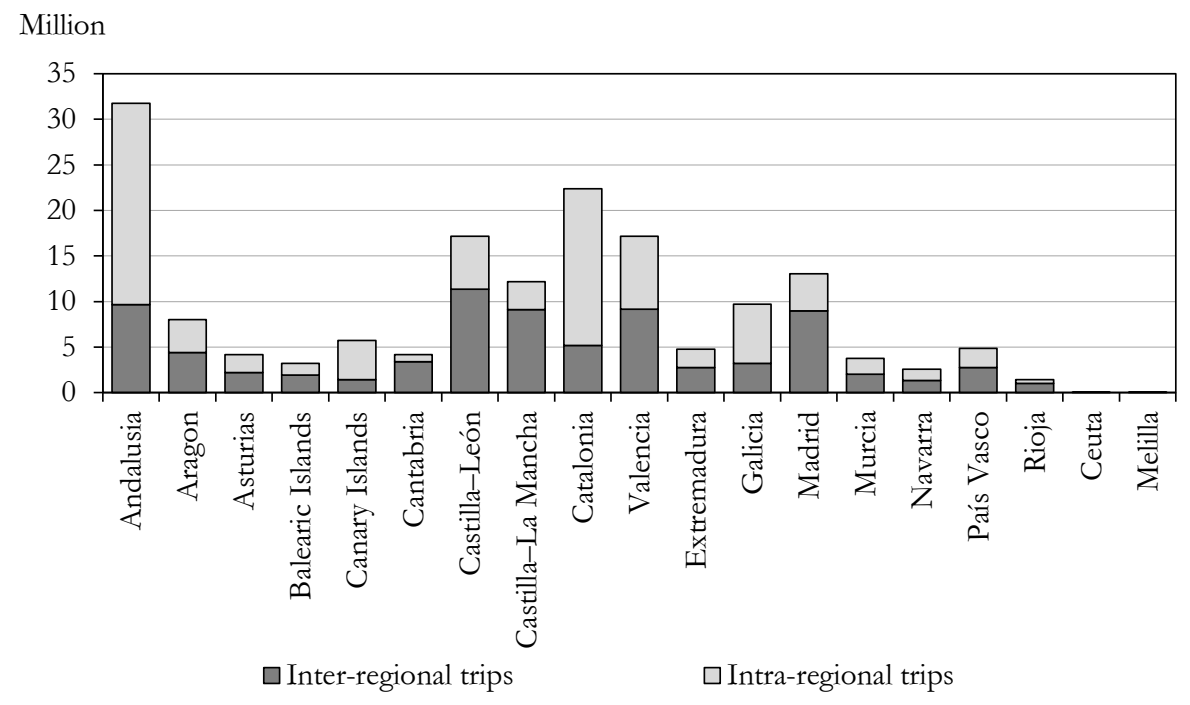

Source: Own elaboration based on the O-D matrix derived from the 2016 FAMILITUR survey.

Regional Statistics, Vol. 7. No. 2. 2017: 3-34; DOI: 10.15196/RS070205 


\section{Description of the inter-regional domestic tourist flows}

The inter-regional domestic tourism amounted to 80.14 million trips in 2016 (48.21\% of the total domestic trips). As can be observed in Figure 2a, most of the trips are concentrated in four regions of destination: Castilla-León (14.18\%), Andalusia (12.07\%), Valencia (11.43\%), and Castilla-La Mancha (11.38\%). Figure 2b shows that Madrid accounts for a very high share of the trips to other regions (33.87\% of the total outbound trips), followed far behind by Catalonia $(9.17 \%)$ and País Vasco $(9.17 \%)$. Considering that these regions are the richest in Spain, this descriptive analysis suggests that income may be one of the push determinants of the demand for inter-regional domestic tourism. Figure 3 a graphically indicates the regions that originate and receive most of the inter-regional trips. This figure also displays the net inter-regional flows. País Vasco, Catalonia and particularly Madrid show a negative flow, meaning that they generate more trips than what they receive. Figure $3 \mathrm{~b}$ presents the outbound trips for each region once we remove the distorting effects caused by the population size. Madrid is the region that has the highest outbound intensity (4.24 trips per capita), followed by País Vasco (3.39 trips) and Ceuta (3.16 trips). The lowest intensity is found in Andalusia (0.58 trips per capita) and Canary Islands (0.47 trips).

Figure 2a

Percentage of inter-regional domestic tourist trips by regions of destination (inbound trips), 2016

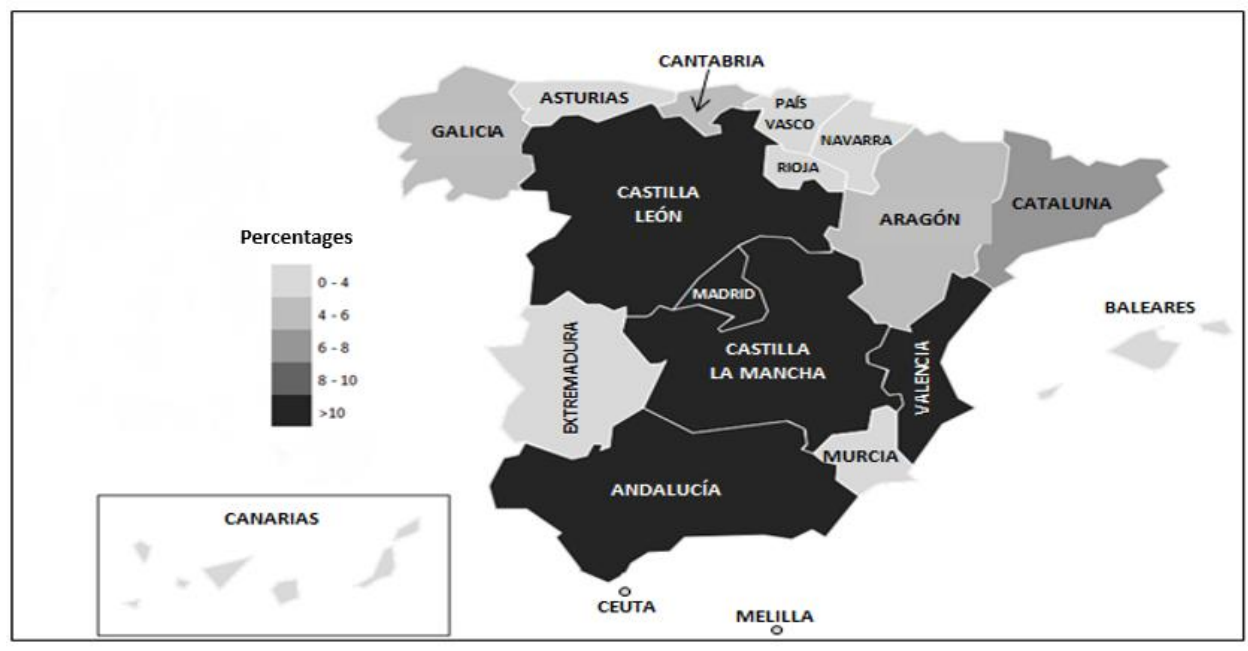

Source: Own elaboration based on the O-D matrix derived from the 2016 FAMILITUR survey. 
Modelling inter- and intra-regional tourism flows in Spain - a spatial econometric approach

Figure $2 b$

Percentage of inter-regional domestic tourist trips by regions of origin (outbound trips), 2016

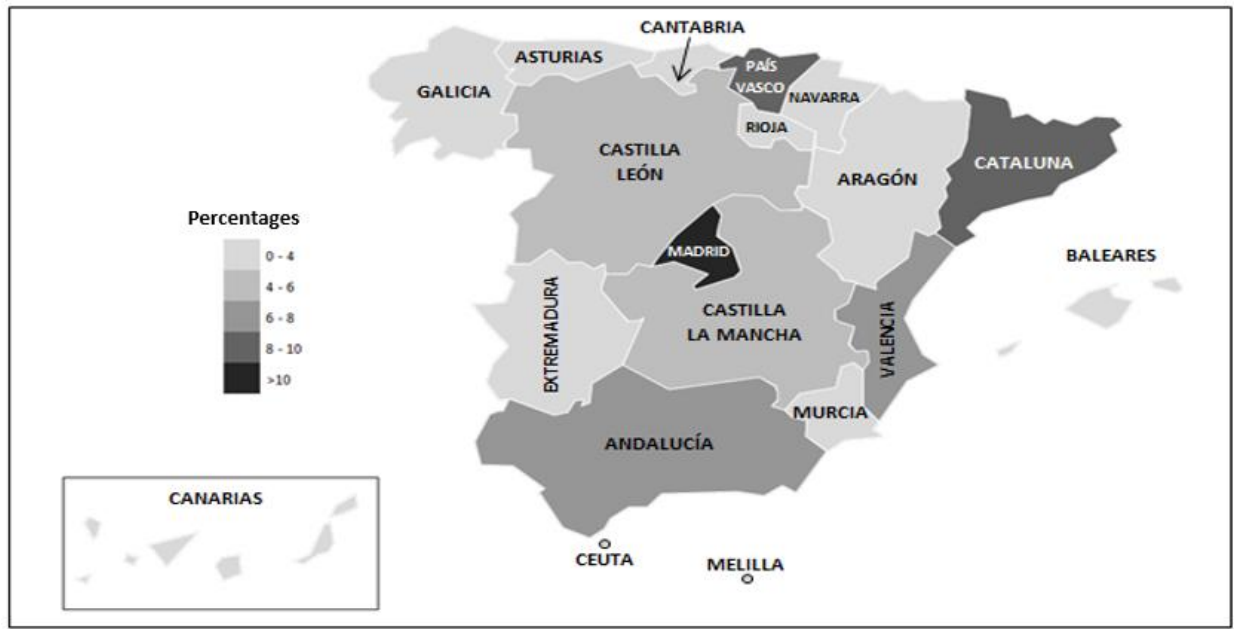

Source: Own elaboration based on the O-D matrix derived from the 2016 FAMILITUR survey.

Figure 3a

Number of inter-regional domestic tourist trips and net flows by regions, 2016

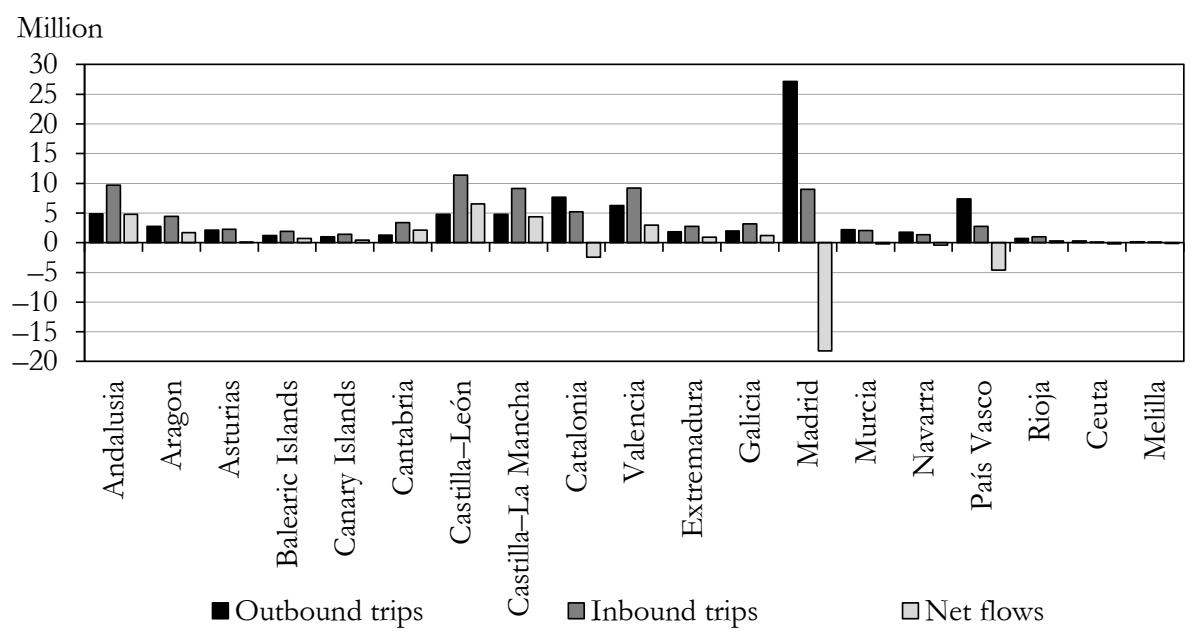

Source: Own elaboration based on the O-D matrix derived from the 2016 FAMILITUR survey. 
Number of inter-regional domestic tourist trips per capita, by regions of origin, 2016

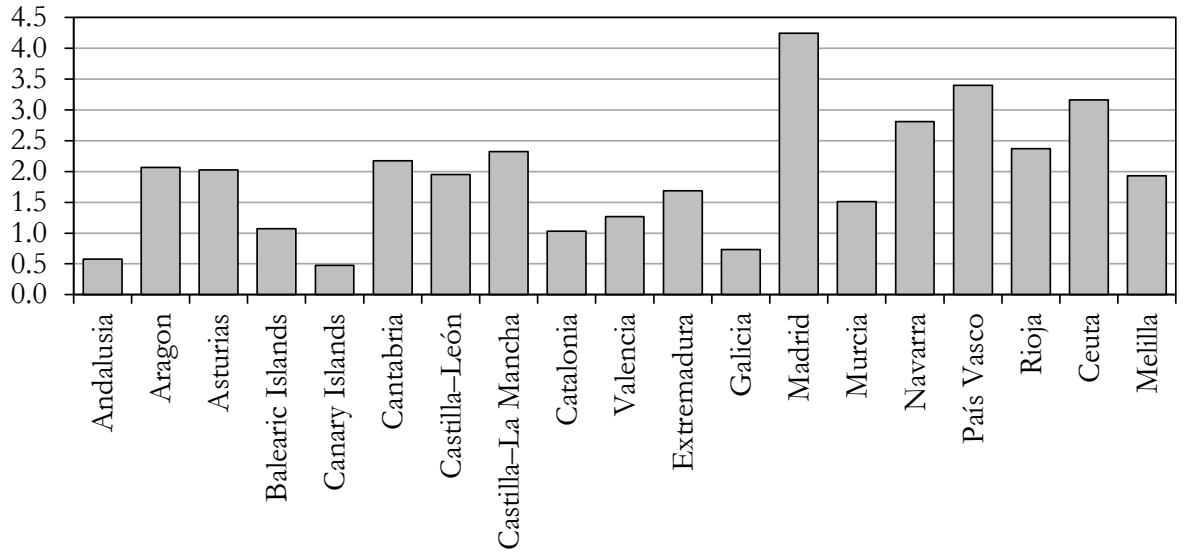

Source: Own elaboration based on the O-D matrix derived from the 2016 FAMILITUR survey.

Following the methodology explained in Guardia-Gálvez et al. (2014) and Dominguez-Pérez (2016), the O-D matrix allows the calculation of the interregional coefficients of tourist attraction. These coefficients indicate the relative level of tourist attraction of each region and are calculated as follows:

$$
c a_{i, j}=\frac{\left(\frac{\text { Domestic trips from region } j \text { to region } i}{\text { Total of domestic trips received in region } i}\right)}{\left(\frac{\text { Number of domestic trips generated in region } j}{\text { Total number of domestic trips }}\right)} .
$$

A region $i$ is considered 'attractive' for residents in region $j$ if the coefficient $c a_{i, j}$ is greater than one; in other words, if inbound trips from region $j$ to region $i$ represented as a fraction of the total inbound flows received by region $i$ is greater than the total outbound trips of region $j$ over the total of trips generated in Spain. Table 2 displays the coefficients of tourist attraction. The rows represent the regions of destination, and the columns the regions of origin. For example, we observe that the region of Aragon is an attractive destination for residents in neighbouring regions, such as Catalonia $\left(c a_{\mathrm{Ara}, \mathrm{Cat}}=3.78\right)$, Valencia $\left(c a_{\mathrm{Ara}, \mathrm{Val}}=2.11\right)$, Navarra $\left(c a_{\mathrm{Ara}, \mathrm{Nav}}=2.11\right)$, La Rioja $\left(c a_{\mathrm{Ara}, \mathrm{Rio}}=1.70\right)$, and País $\operatorname{Vasco}\left(c a_{\mathrm{Ara}, \mathrm{PV}}=1.32\right)$. More generally, we find that Madrid, País Vasco, and Catalonia have the highest number of coefficients greater than one, which suggests that these regions are the most attractive ones for inter-regional tourism. In addition, it appears that there are some neighbouring effects. Indeed, with the only exceptions of the Balearic Islands and Canary Islands, the highest values for the coefficients of tourist attractions are ob-

Regional Statistics, Vol. 7. No. 2. 2017: 3-34; DOI: 10.15196/RS070205 
served in the neighbouring regions of the regions under scrutiny. ${ }^{7}$ Finally, as already commented in Guardia-Gálvez et al. (2014), the magnitude of the coefficients of attraction appear to strongly depend on the geographical distance between regions, and on the population and economic strength of the region of origin.

Table 2

Index of inter-regional tourist attraction by regions of destination, 2016

\begin{tabular}{|c|c|c|c|c|c|c|c|c|c|c|c|c|c|c|c|c|c|c|c|}
\hline & AND & ARA & AST & BAL & CAN & CANT & CYL & $\mathrm{CM}$ & CAT & VAL & EXT & GAL & MAD & MUR & NAV & PV & RIO & CEU & MEL \\
\hline AND & - & 0.44 & 0.55 & 1.52 & 2.04 & 0.40 & 0.54 & 1.29 & 1.12 & 1.21 & 3.68 & 0.64 & 1.05 & 2.27 & 0.53 & 0.38 & 0.42 & 6.84 & 6.06 \\
\hline ARA & 0.41 & - & 0.17 & 0.35 & 0.09 & 0.54 & 0.68 & 0.63 & 3.78 & 2.11 & 0.41 & 0.24 & 0.38 & 0.21 & 2.91 & 1.32 & 1.70 & 0.08 & 0.11 \\
\hline AST & 0.78 & 0.66 & - & 0.33 & 0.65 & 2.52 & 2.62 & 0.43 & 0.48 & 0.51 & 0.54 & 5.14 & 1.01 & 0.19 & 1.25 & 0.97 & 0.71 & 0.14 & 0.13 \\
\hline BAL & 2.13 & 0.41 & 0.54 & - & 1.21 & 0.44 & 0.54 & 0.51 & 3.42 & 1.59 & 0.12 & 1.11 & 0.58 & 0.64 & 0.35 & 0.53 & 0.73 & 0.14 & 0.54 \\
\hline CAN & 1.70 & 0.55 & 1.42 & 2.19 & - & 0.73 & 0.93 & 0.33 & 2.38 & 0.58 & 0.32 & 3.91 & 0.66 & 0.59 & 0.65 & 0.93 & 0.44 & 0.26 & 0.84 \\
\hline CANT & 0.19 & 0.53 & 1.42 & 0.04 & 0.42 & - & 3.16 & 0.19 & 0.38 & 0.22 & 0.22 & 1.06 & 0.51 & 0.13 & 1.07 & 4.65 & 1.66 & 0.06 & 0.00 \\
\hline CYL & 0.45 & 0.54 & 1.89 & 0.30 & 0.23 & 1.88 & - & 0.57 & 0.39 & 0.28 & 0.71 & 1.08 & 1.66 & 0.21 & 0.72 & 1.51 & 0.97 & 0.07 & 0.14 \\
\hline $\mathrm{CM}$ & 0.60 & 0.30 & 0.10 & 0.24 & 0.19 & 0.08 & 0.15 & - & 0.27 & 1.53 & 0.44 & 0.09 & 2.18 & 0.98 & 0.21 & 0.05 & 0.08 & 0.08 & 0.12 \\
\hline CAT & 1.39 & 4.83 & 0.71 & 4.65 & 1.77 & 0.95 & 0.78 & 0.58 & - & 1.92 & 0.52 & 0.92 & 0.53 & 0.74 & 2.24 & 1.01 & 1.81 & 0.19 & 0.15 \\
\hline VAL & 0.95 & 1.72 & 0.44 & 0.59 & 0.38 & 0.29 & 0.95 & 2.18 & 1.45 & - & 0.22 & 0.55 & 1.08 & 2.71 & 0.69 & 0.49 & 0.84 & 0.12 & 0.30 \\
\hline EXT & 2.79 & 0.31 & 0.36 & 0.29 & 0.49 & 0.61 & 0.98 & 0.89 & 0.42 & 0.36 & - & 0.43 & 1.55 & 0.24 & 0.21 & 0.68 & 0.04 & 0.30 & 0.34 \\
\hline GAL & 1.02 & 0.65 & 4.97 & 0.78 & 3.08 & 1.40 & 3.01 & 0.43 & 1.12 & 0.34 & 0.47 & - & 0.72 & 0.50 & 0.40 & 0.96 & 0.75 & 0.21 & 0.23 \\
\hline MAD & 2.48 & 0.99 & 1.44 & 1.97 & 2.51 & 1.51 & 1.74 & 2.56 & 0.87 & 1.48 & 2.13 & 2.37 & - & 1.20 & 0.77 & 0.74 & 1.01 & 0.36 & 0.81 \\
\hline MUR & 1.97 & 0.48 & 0.47 & 0.38 & 0.10 & 0.14 & 0.33 & 2.04 & 0.73 & 3.83 & 0.26 & 0.28 & 0.90 & - & 0.20 & 0.05 & 0.18 & 1.36 & 1.10 \\
\hline NAV & 0.62 & 2.94 & 0.74 & 0.14 & 0.37 & 0.69 & 1.55 & 0.28 & 1.29 & 0.42 & 0.27 & 0.17 & 0.43 & 0.20 & - & 3.82 & 5.27 & 0.27 & 0.25 \\
\hline PV & 1.27 & 1.14 & 1.26 & 0.80 & 1.15 & 5.05 & 2.57 & 0.32 & 1.44 & 0.81 & 0.55 & 1.21 & 0.49 & 0.26 & 5.16 & - & 4.17 & 0.10 & 0.06 \\
\hline RIO & 0.18 & 1.28 & 0.83 & 0.54 & 0.14 & 1.77 & 0.94 & 0.15 & 0.23 & 0.28 & 0.18 & 0.51 & 0.44 & 0.15 & 2.60 & 5.98 & - & 0.04 & 0.00 \\
\hline CEU & 15.22 & 0.00 & 0.00 & 0.00 & 0.00 & 0.00 & 0.00 & 0.00 & 0.00 & 0.00 & 0.00 & 0.00 & 0.15 & 0.00 & 0.00 & 0.00 & 0.00 & - & 13.32 \\
\hline MEL & $|12.70|$ & 0.93 & 0.00 & 0.00 & 0.00 & 0.00 & 0.00 & 0.00 & \begin{tabular}{|l|l} 
& 0.44
\end{tabular} & 0.00 & 0.00 & 0.00 & 0.00 & 3.62 & 0.00 & 0.00 & 0.00 & $|16.73|$ & - \\
\hline
\end{tabular}

Note. The abbreviations used in the table stand for the following: AND - Andalusia, ARA - Aragon, AST Asturias, BAL - Balearic Islands, CAN - Canary Islands, CANT - Cantabria, CYL - Castilla-León, CM - CastillaLa Mancha, CAT - Catalonia, VAL - Valencia, EXT - Extremadura, GAL - Galicia, MAD - Madrid, MUR Murcia, NAV - Navarra, PV - País Vasco, RIO - Rioja, CEU - Ceuta, MEL - Melilla. The rows represent the regions of destination; the columns show the regions of origin. Values greater than 1 are in grey cells; they refer to strong tourist attraction.

Source: Own calculation following the instructions given in Guardia-Gálvez et al. (2014) and Domínguez-Pérez (2016), and using the O-D matrix based on the 2016 FAMILITUR survey.

${ }^{7}$ It is interesting to highlight the strong neighbouring effect observed for the cases of Ceuta and Melilla. These cities are located in Africa, and not well linked with the rest of Spain. The coefficients of attraction for Ceuta show values greater than one, and extremely high only for the flows from the regions of Andalusia and Melilla $\left(c a_{\mathrm{Ceu}, \mathrm{And}}=15.22\right.$ and $\left.c a_{\mathrm{Ceu}, \mathrm{Mel}}=13.32\right)$. This means that Ceuta is only an attractive destination for these two regions; but this is not a surprising finding given that the only connection of Ceuta to mainland Spain is by boat to Andalusia and by road to Melilla. The same can be observed in the case of Melilla.

Regional Statistics, Vol. 7. No. 2. 2017: 3-34; DOI: 10.15196/RS070205 


\section{Description of the intra-regional domestic tourist flows}

The intra-regional domestic tourism is an important component of the flows of domestic tourism. This type of tourism corresponds to more than 86 million trips in 2016; that is $51.79 \%$ of the total number of domestic trips. However, the amount spent per person and day is equal to only 31 euros, a figure low in comparison to the 52 euros per person and day in the case of inter-regional trips.

According to Figure 4a, the residents of Andalusia and Catalonia are the ones who travel the most within their respective regions (22.08 million of trips for Andalusia and 17.21 million of trips for Catalonia). Figure $4 \mathrm{~b}$ depicts the intensity of intra-regional tourism after controlling for the population size of the regions.

Number of intra-regional domestic tourist trips, 2016

Figure 4a

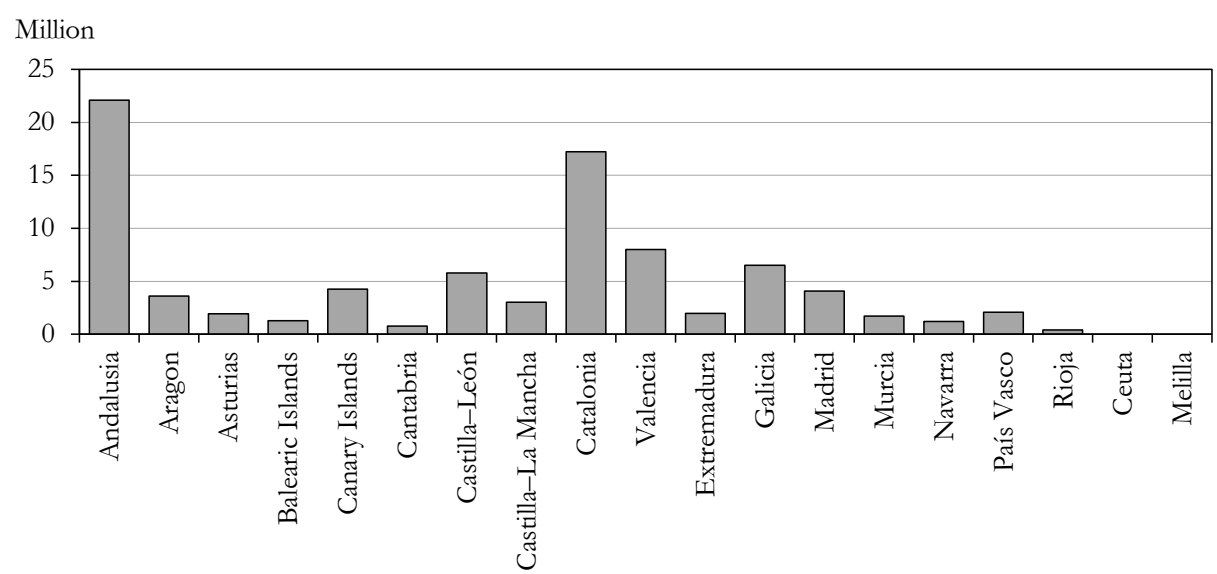

Source: Own elaboration based on the O-D matrix derived from the 2016 FAMILITUR survey.

Number of intra-regional domestic tourist trips per capita, 2016

Figure 4b

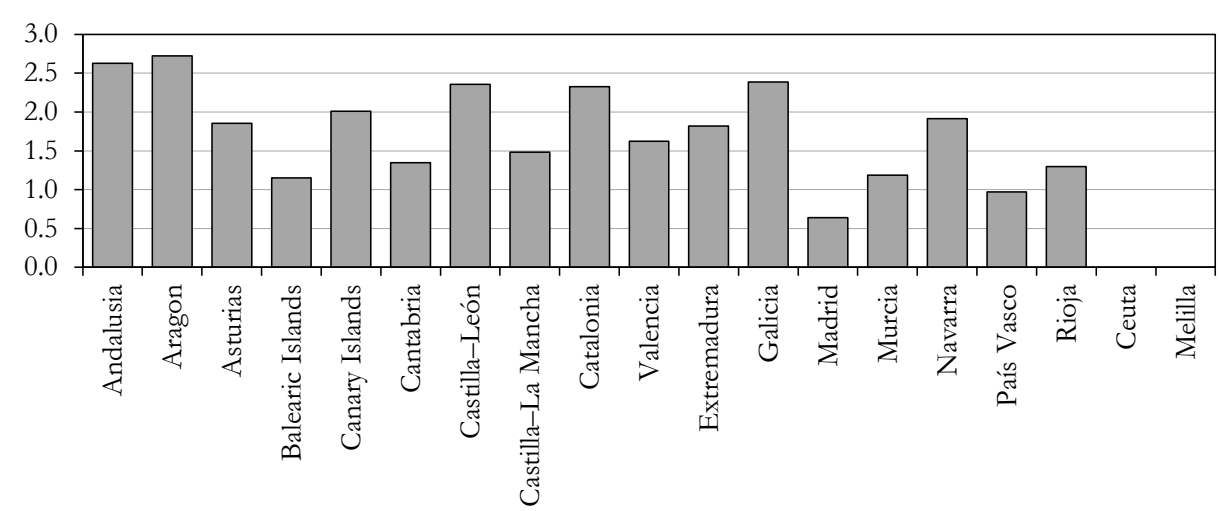

Source: Own elaboration based on the O-D matrix derived from the 2016 FAMILITUR survey.

Regional Statistics, Vol. 7. No. 2. 2017: 3-34; DOI: 10.15196/RS070205 
Modelling inter- and intra-regional tourism flows in Spain - a spatial econometric approach

The highest intensity of trips is observed for the residents of Aragon (2.72 intraregional trips per capita), Andalusia (2.63 trips per capita), Galicia (2.38 trips per capita), and Catalonia (2.33 trips per capita), while on the contrary, the lowest intensity of trips is registered for the residents of Madrid (0.69 trips per capita) and La Rioja (1.30 trips per capita).

Figures $5 \mathrm{a}$ and $5 \mathrm{~b}$ graphically illustrate the relative importance of intra-regional domestic tourism. In the case of inbound trips (see Figure 5a), the share of intraregional trips with respect to the total number of domestic trips is the highest in the regions of Catalonia (76.87\%), Canary Islands (74.80\%), and Andalusia (69.54\%). The lowest percentages of intra-regional tourism are found in the regions of Madrid $(31.28 \%)$ and La Rioja (28.31\%). Figure 5b shows the corresponding figures for the outbound trips. Andalusia, Canary Islands, and Galicia are the regions of destination with the highest percentages of domestic trips being intra-regional $(81.95,80.90$, and $76.59 \%$, respectively), whilst on the contrary, Madrid shows the lowest proportion $(13.04 \%)$.

Figure 5a

Percentage of intra-regional domestic tourist trips in the total number of domestic inbound trips, 2016

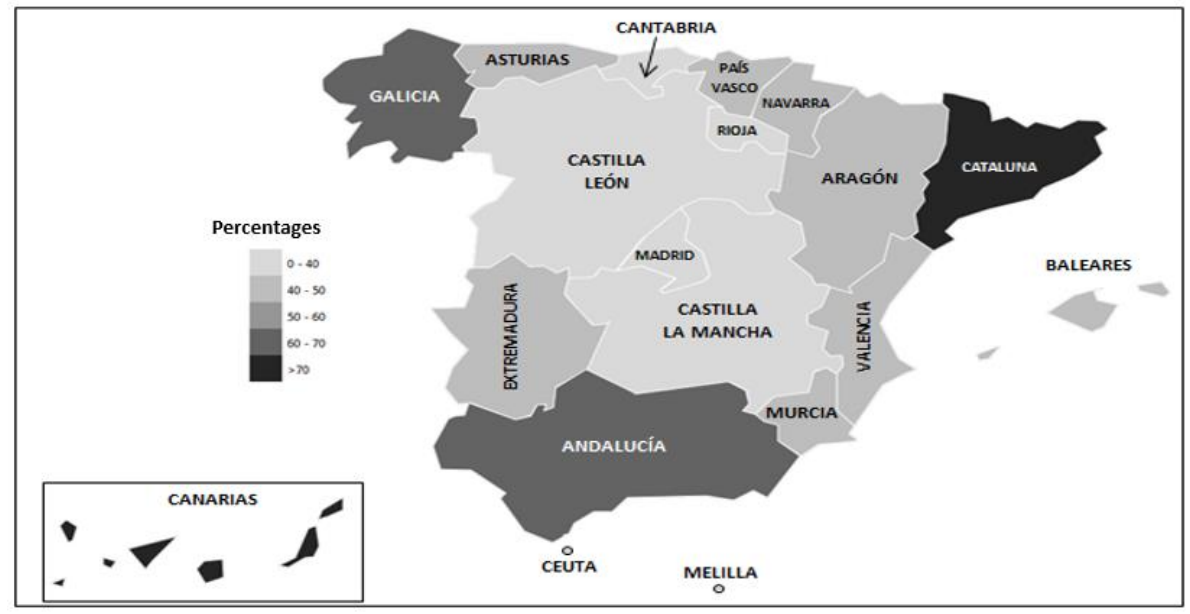

Source: Own elaboration based on the O-D matrix derived from the 2016 FAMILITUR survey.

Regional Statistics, Vol. 7. No. 2. 2017: 3-34; DOI: 10.15196/RS070205 
Percentage of intra-regional domestic tourist trips in the total number of

Figure $5 b$ domestic outbound trips, 2016

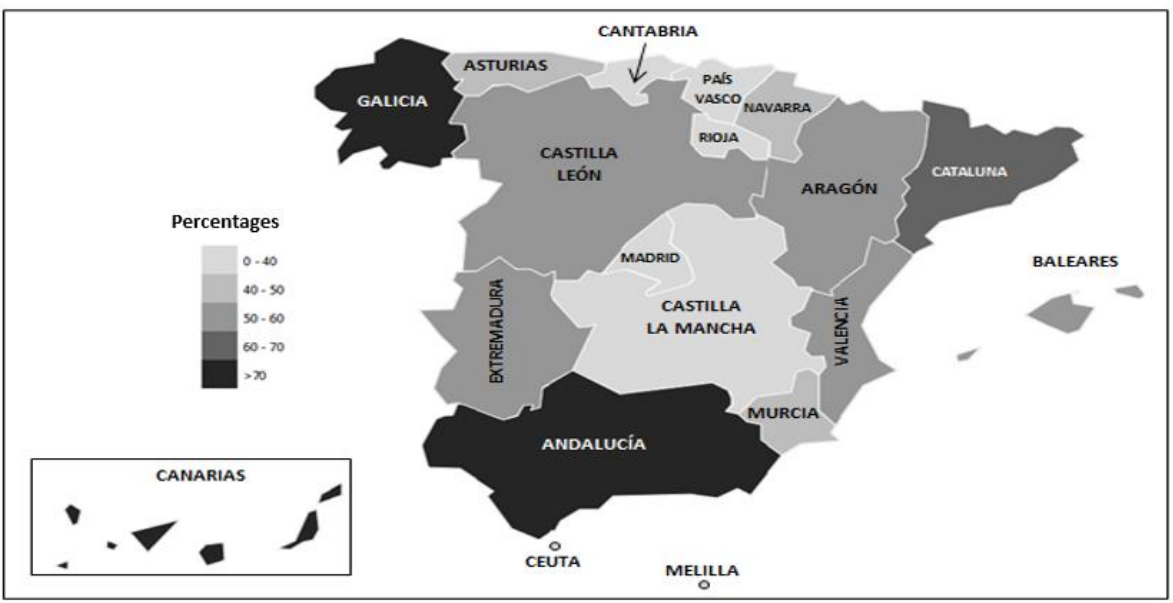

Source: Own elaboration based on the O-D matrix derived from the 2016 FAMILITUR survey.

\section{Econometric model and variables}

The econometric modelling procedure assumes that the domestic tourist flows for Spain in the year 2016 can be appropriately represented by the following SAR model:

$$
Y=\mathbf{X}_{\text {Inter }}^{\mathrm{D}} \cdot \boldsymbol{\beta}_{\text {Inter }}^{D}+\mathbf{X}_{\text {Inter }}^{\mathrm{O}} \cdot \boldsymbol{\beta}_{\text {Inter }}^{O}+\gamma \cdot D+\theta \cdot P+\mathbf{X}_{\text {Intra }} \cdot \boldsymbol{\beta}_{\text {Intra }}+\varrho \cdot W \cdot Y+\mathbf{U},
$$

where $Y$ measures domestic tourism and is proxied by the logged number of tourist trips from a region of origin (I) to a region of destination $(J)$. The matrices $\mathbf{X}_{\text {Inter }}^{\mathrm{D}}$ and $\mathrm{X}_{\mathrm{Inter}}^{\mathrm{O}}$, and the variables $D$ and $P$ denote the determinants of inter-regional flows. $\mathbf{X}_{\text {Inter }}^{\mathrm{D}}$ includes measures of the economic characteristics (GDP per capita) and accessibility (number of airports) of the regions of destination as well as proxies for their cultural, recreational, and natural attractiveness. More specifically, attractiveness is measured with an indicator of beaches' quality, number of theme and national parks, and number of museums in the destination region under consideration. Equation (2) also includes dummies for island and autonomous cities as both may exhibit specific patterns to be accounted for.

The matrix $\mathbf{X}_{\text {Inter }}^{\mathrm{O}}$ includes the characteristics of the region of origin that are likely to affect domestic flows. This comprises of the GDP per capita as well as the population size and level of accessibility (number of airports) of the region of origin. As previously stated, we also include dummy variables for regions of origin that are either island or autonomous cities. The geographical distance $(D)$ and relative pric-

Regional Statistics, Vol. 7. No. 2. 2017: 3-34; DOI: 10.15196/RS070205 
es $(P)$ between regions are also included in equation (2) in order to account for travelling cost and cost of living differences between regions of destination and origin. On the other hand, we assume that intra-regional flows can be explained by the variables grouped in the matrix $\mathbf{X}_{\text {Intra }}$, namely, the GDP per capita, population size of the region, and the two dichotomous variables indicating if the region is an island or an autonomous city. ${ }^{8}$ Note that the variables GDP per capita, $P$, and population are transformed into logarithms so that their coefficients can be directly interpreted as elasticities.

The selection of the variables included in the matrices $\mathrm{X}_{\text {Inter }}^{\mathrm{O}}, \mathrm{X}_{\text {Inter }}^{\mathrm{D}}, \mathrm{X}_{\text {Intra }}$ follows Marrocu and Paci (2013), Guardia-Gálvez et al. (2014), and De la Mata and Llano-Verduras (2012). Table 3 provides a detailed description of each of the variables used in equation (2) as well as their data sources, whilst Table 4 displays the summary statistics of the explanatory variables at the regional level.

Table 3

Variables used in the SAR model to explain the inter-regional flows in Spain

\begin{tabular}{|c|c|c|c|}
\hline Variable & Definition & Description & Source \\
\hline \multicolumn{4}{|c|}{ Region of destination ( $\mathbf{X}_{\text {Inter }}^{\mathrm{D}}$ ) } \\
\hline $\begin{array}{l}\text { GDP per } \\
\text { capita }\end{array}$ & $\begin{array}{l}\text { Natural logarithm of the re- } \\
\text { gional GDP per capita in the } \\
\text { region of destination in } 2015\end{array}$ & $\begin{array}{l}\text { Indicator of the economic de- } \\
\text { velopment level of the region } \\
\text { of destination (quality of public } \\
\text { services and institutions) }\end{array}$ & $\begin{array}{c}\text { INE } \\
\text { www.ine.es }\end{array}$ \\
\hline $\begin{array}{l}\text { Blue Flag } \\
\text { beaches }\end{array}$ & $\begin{array}{l}\text { Number of Blue Flag beaches } \\
\text { in the region of destination, } \\
2015\end{array}$ & $\begin{array}{l}\text { Indicator of the capacity to } \\
\text { attract 'sun-and-beach' visitors }\end{array}$ & $\begin{array}{c}\text { FEE } \\
\text { www.blueflag.global }\end{array}$ \\
\hline Museums & $\begin{array}{l}\text { Total number of museums in } \\
\text { the region of destination, } 2015\end{array}$ & $\begin{array}{l}\text { Indicator of the capacity to } \\
\text { attract cultural visitors }\end{array}$ & $\begin{array}{c}\text { MECD } \\
\text { www.mecd.gob.es }\end{array}$ \\
\hline Theme parks & $\begin{array}{l}\text { Total number of theme parks } \\
\text { in the region of destination, } \\
2015\end{array}$ & $\begin{array}{l}\text { Indicator of the capacity to } \\
\text { attract recreational tourism }\end{array}$ & $\begin{array}{c}\text { TOURESPAÑA } \\
\text { www.spain.info/en }\end{array}$ \\
\hline Natural parks & $\begin{array}{l}\text { Total number of national natu- } \\
\text { ral parks in the region of desti- } \\
\text { nation, } 2015\end{array}$ & $\begin{array}{l}\text { Indicator to measure the capac- } \\
\text { ity of the natural amenities to } \\
\text { attract visitors }\end{array}$ & $\begin{array}{c}\text { MAPAMA } \\
\text { www.mapama.gob.es }\end{array}$ \\
\hline
\end{tabular}

\footnotetext{
${ }^{8}$ The variables were transformed to adapt them to an O-D modelling framework. Thus, $Y$ was obtained from the vectorisation of the O-D matrix, and $D$ and $P$ from the vectorisation of the symmetric $n \times n$ matrices of geographical distances and relative prices, respectively. The matrices $\mathbf{X}_{\text {Inter }}^{\mathrm{D}}, \mathbf{X}_{\text {Inter }}^{\mathrm{O}}$, and $\mathbf{X}_{\text {Intra }}$ were accordingly transformed by using the Kronecker product. Moreover, the main diagonal of the matrices $\mathbf{X}_{\text {Inter }}^{\mathrm{D}}$ and $\mathbf{X}_{\text {Inter }}^{\mathrm{O}}$ was set to zero to isolate the intra-regional trips. Considering the same reason, the off-diagonal of $\mathbf{X}_{\text {Intra }}$ was set to zero to not consider the inter-regional trips. For a more detailed explanation of these transformations, the reader referred to Lesage and Pace (2008) and Marrocu and Paci (2013).
}

Regional Statistics, Vol. 7. No. 2. 2017: 3-34; DOI: 10.15196/RS070205 
(Continuation.)

\begin{tabular}{|c|c|c|c|}
\hline Variable & Definition & Description & Source \\
\hline \multicolumn{4}{|c|}{ Region of destination ( $\mathbf{X}_{\text {Inter }}^{\mathrm{D}}$ ) } \\
\hline Airports & $\begin{array}{l}\text { Total number of airports in the } \\
\text { region of destination, } 2016\end{array}$ & $\begin{array}{l}\text { Indicator that approximates the } \\
\text { level of accessibility of the re- } \\
\text { gion of destination }\end{array}$ & $\begin{array}{c}\text { AENA } \\
\text { www.aena.es }\end{array}$ \\
\hline Island & $\begin{array}{l}\text { Dummy variable that takes } \\
\text { value } 1 \text { if the region of destina- } \\
\text { tion is an island }\end{array}$ & $\begin{array}{l}\text { Indicator that takes into con- } \\
\text { sideration whether the region } \\
\text { of destination is an island (Bal- } \\
\text { earic Islands and Canary Is- } \\
\text { lands) }\end{array}$ & Own calculation \\
\hline $\begin{array}{l}\text { Autonomous } \\
\text { city }\end{array}$ & $\begin{array}{l}\text { Dummy variable that takes } \\
\text { value } 1 \text { if the region of destina- } \\
\text { tion is an autonomous city }\end{array}$ & $\begin{array}{l}\text { Indicator that takes into con- } \\
\text { sideration whether the region } \\
\text { of destination is an autono- } \\
\text { mous city (Ceuta and Melilla) }\end{array}$ & Own calculation \\
\hline \multicolumn{4}{|c|}{ Region of origin ( $\mathbf{X}_{\text {Inter }}^{\mathrm{O}}$ ) } \\
\hline $\begin{array}{l}\text { GDP per } \\
\text { capita }\end{array}$ & $\begin{array}{l}\text { Natural logarithm of the regional } \\
\text { GDP per capita in the region of } \\
\text { origin, } 2016\end{array}$ & $\begin{array}{l}\text { Indicator of the level of income } \\
\text { of residents in the region of } \\
\text { origin }\end{array}$ & $\begin{array}{c}\text { INE } \\
\text { www.ine.es }\end{array}$ \\
\hline Population & $\begin{array}{l}\text { Natural logarithm of the popula- } \\
\text { tion in the region of origin, } 2016\end{array}$ & $\begin{array}{l}\text { Indicator of the size of the popu- } \\
\text { lation in the region of origin }\end{array}$ & $\begin{array}{l}\text { INE } \\
\text { www.ine.es }\end{array}$ \\
\hline Airports & $\begin{array}{l}\text { Total number of airports in the } \\
\text { region of origin, } 2016\end{array}$ & $\begin{array}{l}\text { Indicator that approximates the } \\
\text { level of accessibility of the region } \\
\text { of origin }\end{array}$ & $\begin{array}{c}\text { AENA } \\
\text { www.aena.es }\end{array}$ \\
\hline Island & $\begin{array}{l}\text { Dummy variable that takes value } \\
1 \text { if the region of origin is an } \\
\text { island }\end{array}$ & $\begin{array}{l}\text { Indicator that takes into consid- } \\
\text { eration whether visitors come } \\
\text { from an island (Balearic Islands } \\
\text { and Canary Islands) }\end{array}$ & Own calculation \\
\hline $\begin{array}{l}\text { Autonomous } \\
\text { city }\end{array}$ & $\begin{array}{l}\text { Dummy variable that takes value } \\
1 \text { if the region of origin is an } \\
\text { autonomous city }\end{array}$ & $\begin{array}{l}\text { Indicator that takes into consid- } \\
\text { eration whether visitors come } \\
\text { from an autonomous city (Ceuta } \\
\text { and Melilla) }\end{array}$ & Own calculation \\
\hline \multicolumn{4}{|c|}{ Bilateral variables } \\
\hline $\begin{array}{l}\text { Relative } \\
\text { prices }\end{array}$ & $\begin{array}{l}\text { Natural logarithm of the relative } \\
\text { consumer price index (tourism } \\
\text { and hospitality) between the } \\
\text { region of origin and the region of } \\
\text { destination, } 2015\end{array}$ & $\begin{array}{l}\text { Proxy of the relative cost of liv- } \\
\text { ing between the region of origin } \\
\text { and the region of destination }\end{array}$ & $\begin{array}{c}\text { INE } \\
\text { www.ine.es }\end{array}$ \\
\hline $\begin{array}{l}\text { Geographical } \\
\text { distance }\end{array}$ & $\begin{array}{l}\text { Geographical distance in kilome- } \\
\text { tres between the region of origin } \\
\text { and the region of destination }\end{array}$ & $\begin{array}{l}\text { Proxy of the cost of travelling } \\
\text { from region of origin to the re- } \\
\text { gion of destination (transport } \\
\text { and opportunity costs) }\end{array}$ & Own calculation \\
\hline
\end{tabular}

Note: The abbreviations used in the table stand for the following: INE - Spanish National Statistics, FEE - Foundation for Environmental Education, MECD - Spanish Ministry of Education, Culture and Sports, MAPAMA - Spanish Ministry of Agriculture, Food and Environment, TOURESPAÑA - a tourism agency that is dependent on the Spanish Ministry of Energy, Tourism and Digital Agenda, AENA - a Spanish airport operations company. The geographical distances between regions were calculated by using MATLAB, based on the regions' longitude and latitude.

For several variables, 2015 data were used as the values for 2015 and 2016 are similar or, in many cases, the same, and assuming that visitors have made their decisions according to their perceptions formed in the previous year.

Regional Statistics, Vol. 7. No. 2. 2017: 3-34; DOI: 10.15196/RS070205 


\section{Main descriptive statistics of the regional-level variables}

Table 4

\begin{tabular}{|c|c|c|c|c|}
\hline Variable & Mean & $\begin{array}{l}\text { Standard } \\
\text { deviation }\end{array}$ & Maximum & Minimum \\
\hline $\begin{array}{l}\text { Intra-regional tourism flows } \\
\text { (number of visitors) }\end{array}$ & $4,530,480$ & $5,823,391$ & $22,086,482$ & 0 \\
\hline Inter-regional tourist flows & & & & \\
\hline $\begin{array}{l}\text { to the region } \\
\text { (number of visitors) }\end{array}$ & $4,217,877$ & $3,604,605$ & $11,367,619$ & 39,957 \\
\hline $\begin{array}{l}\text { from the region } \\
\text { (number of visitors) }\end{array}$ & $4,217,877$ & $6,016,794$ & $27,145,486$ & 163,513 \\
\hline $\begin{array}{l}\text { Geographical distance (kilo- } \\
\text { metre) }\end{array}$ & 564.16 & 468.07 & 2,170 & 0 \\
\hline $\begin{array}{l}\text { Relative prices (consumer } \\
\text { price index) (euro) }\end{array}$ & 100.05 & 0.43 & 101.77 & 99.27 \\
\hline GDP per capita (euro) & 22,260 & $4,806.5$ & 31,708 & 15,882 \\
\hline Number of museums & 28 & 21 & 84 & 1 \\
\hline Number of Blue Flag beaches & 30 & 44 & 131 & 0 \\
\hline Number of national parks & 1 & 1 & 4 & 0 \\
\hline Number of theme parks & 2 & 3 & 8 & 0 \\
\hline Number of airports & 2 & 2 & 8 & 0 \\
\hline Dummy variable & \multicolumn{4}{|c|}{ Frequency } \\
\hline Autonomous city & \multicolumn{4}{|c|}{$10.53 \%$} \\
\hline Island & \multicolumn{4}{|c|}{$10.53 \%$} \\
\hline
\end{tabular}

Source: Here and in the following tables, own calculation.

The parameters to be estimated in the model are $\gamma, \theta, \varrho$, and those included in the vectors $\boldsymbol{\beta}_{\text {Inter }}^{D}, \boldsymbol{\beta}_{\text {Inter }}^{o}$, and $\boldsymbol{\beta}_{\text {Intra }}$. We opt for a SAR econometric specification in order to control for spatial dependence at the tourist destination. ${ }^{9}$ The possible existence of spillover effects are captured by the term $\mathbf{W} \cdot Y$, with $\mathbf{W}$ being the queen contiguity-weighting matrix. ${ }^{10}$ Therefore, $\mathbf{W} \cdot Y$ is the weighted average of the tourism flows of neighbouring regions. The parameter $\varrho$ is the SAR parameter, which measures the degree of spatial dependence among the regions of destination. If $\varrho=0$, then the specification of the model (2) is the same as the one of the gravity

\footnotetext{
${ }^{9}$ LeSage and Pace (2008) find two main motivations for the use of spatial econometric models. The first one is that spatial dependence can be interpreted as a long-run equilibrium of an underlying spatiotemporal process. The second motivation is to avoid the effect of omitted variables that exhibit spatial dependence.

${ }^{10}$ The matrix $\mathbf{W}$ is an exogenous pre-specified spatial matrix with fixed weights, which is the most widely used approach within a linear regression framework (Vega-Elhorst 2015). More specifically, the elements of $\mathbf{W}\left(\mathbf{W}_{\mathbf{i j}}\right)$ are set to be one if region $i$ shares its border with the region of destination $j$, and zero otherwise. The rows of this matrix have been normalised to sum to unity.
}

Regional Statistics, Vol. 7. No. 2. 2017: 3-34; DOI: 10.15196/RS070205 
model. The gravity model is one of the most popular specifications when it comes to the study of regional international flows of goods, migration, investment, and more recently, tourism (Morley et al. 2014). For comparison purposes, in Chapter 4, we also report the results when a gravity model is employed. The gravity model is used as a benchmark to compare the performance of the proposed SAR model and verify the existence of significant spatial spillover effects. Finally, the last term of equation (2), the vector $\mathbf{U}$, is the disturbances of the model, which is assumed an independent and identically distributed random variable.

Unlike the case of the gravity model, the estimated parameters of the SAR model do not provide a direct interpretation of the impact of the explanatory variables on $Y$. The reason for this is that, due to the presence of the spatially lagged term $(\mathbf{W} \cdot Y)$, the parameters of the model do not represent the true partial derivatives of $Y$ with respect to changes in the explanatory variables. LeSage and Pace (2009) show that the partial derivative matrix of $Y$ with respect to the $k^{\text {th }}$ explanatory variable in the $i^{\text {th }}$ region is given by

$$
\frac{\partial Y}{\partial X_{k i}}=\left(\mathbf{I}_{n}-\varrho \cdot \mathbf{W}\right)^{-1} \cdot\left(\beta \cdot \mathbf{I}_{n}\right),
$$

where $\mathbf{I}_{n}$ is the $n \times n$ identity matrix. Despite the complexity of the calculation, the advantage of such a procedure is that the total impact on domestic flows, that is, $Y$ produced by any change in one of the explanatory variables can be decomposed into two effects: direct and indirect effects.

The direct effect reflect the impact on domestic tourism of any change in one of the explanatory variables originated in a region, while the indirect effect measures the impact of the same variable in its neighbouring regions. LeSage and Pace (2009) propose to use the average of the elements of the main diagonal as a summary indicator of the direct effect, and the average of the off-diagonal elements as a summary of the indirect effect. The total effect is calculated as the sum of the direct and indirect effects. In order to identify the statistical distribution of these impacts, the same authors recommend the use of some efficient computational simulation method to assess the statistical significance of the estimated direct, indirect, and total effects. In this paper, we decide to use the same bootstrap procedure as the one explained in Ferson et al. (2013) and Álvarez-Díaz and Gupta (2016). ${ }^{11}$

\section{Empirical results}

Table 5 shows the estimation results of the parameters of equation (2).

\footnotetext{
${ }^{11}$ More specifically, the procedure begins with the construction of 10,000 artificial samples by resampling with replacement of the original data. These artificial samples are used to obtain 10,000 estimates for each one of the parameters of our model represented in equation (2).
}

Regional Statistics, Vol. 7. No. 2. 2017: 3-34; DOI: 10.15196/RS070205 
Modelling inter- and intra-regional tourism flows in Spain - a spatial econometric approach

Table 5

Econometric estimates of the gravity and SAR models

\begin{tabular}{|c|c|c|c|c|}
\hline \multirow[b]{2}{*}{ Variable } & \multicolumn{2}{|c|}{ Gravity model } & \multicolumn{2}{|c|}{ SAR model } \\
\hline & $\begin{array}{c}\text { Point } \\
\text { estimate }\end{array}$ & $\begin{array}{c}\text { Confidence } \\
\text { interval }\end{array}$ & $\begin{array}{c}\text { Point } \\
\text { estimate }\end{array}$ & $\begin{array}{c}\text { Confidence } \\
\text { interval }\end{array}$ \\
\hline \multicolumn{5}{|c|}{ Inter-regional tourism } \\
\hline Region of destination & & & & \\
\hline GDP per capita & 0.820 & {$[0.026,1.670]$} & $1.151 * *$ & {$[0.284,2.011]$} \\
\hline Blue Flag beaches & $0.005^{* * *}$ & {$[0.002,0.009]$} & $0.005^{* *}$ & {$[0.002,0.009]$} \\
\hline Museums & 0.009 & {$[-0.003,0.020]$} & $0.011 *$ & {$[-0.001,0.022]$} \\
\hline Theme parks & $0.137 * * *$ & {$[0.080,0.193]$} & $0.151^{* * *}$ & {$[0.096,0.204]$} \\
\hline Natural parks & $0.490^{* * *}$ & {$[0.207,0.816]$} & $0.561 * * *$ & {$[0.261,0.898]$} \\
\hline Airports & $0.186^{* *}$ & {$[0.049,0.334]$} & $0.171 * *$ & {$[0.039,0.319]$} \\
\hline Island & 0.105 & {$[0.053,0.338]$} & $1.176^{* *}$ & {$[0.402,2.114]$} \\
\hline Autonomous city & $-7.363 * * *$ & {$[-8.478,-5.923]$} & $-7.246^{* * *}$ & {$[-8.369,-5.853]$} \\
\hline \multicolumn{5}{|l|}{ Region of origin } \\
\hline GDP per capita & $1.343^{* * *}$ & {$[0.558,2.055]$} & $1.090^{* * *}$ & {$[0.240,1.772]$} \\
\hline Population & $0.763^{* * *}$ & {$[0.593,0.904]$} & $0.676^{* * *}$ & {$[0.458,0.896]$} \\
\hline Airports & $0.230^{* * *}$ & {$[0.084,0.424]$} & $0.232^{* * *}$ & {$[0.087,0.424]$} \\
\hline Island & 0.056 & {$[-0.424,0.787]$} & 0.099 & {$[-0.547,0.943]$} \\
\hline Autonomous city & -0.264 & {$[-1.175,0.798]$} & -0.201 & {$[-1.124,0.823]$} \\
\hline \multicolumn{5}{|l|}{ Bilateral } \\
\hline Relative prices & $-3.615^{* *}$ & {$[-5.805,-1.337]$} & $-3.944 * * *$ & {$[-6.066,-1.653]$} \\
\hline Geographical distance & $-0.003^{* * *}$ & {$[-0.004,-0.002]$} & $-0.003 * * *$ & {$[-0.004,-0.002]$} \\
\hline \multicolumn{5}{|c|}{ Intra-regional tourism } \\
\hline GDP per capita & $2.306^{* * *}$ & {$[1.293,3.329]$} & $2.333^{* * *}$ & {$[1.271,3.297]$} \\
\hline Population & $0.844 * *$ & {$[0.271,1.163]$} & $1.116^{* * *}$ & {$[0.513,1.537]$} \\
\hline Island & -0.324 & {$[-0.806,0.001]$} & 1.370 & {$[-0.001,2.789]$} \\
\hline Autonomous city & $-13.000 * * *$ & {$[-16.397,-0.001]$} & $-10.866^{* * *}$ & {$[-12.790,-0.010]$} \\
\hline $\mathbf{W} \cdot Y$ & - & & $0.096 * * *$ & {$[0.048,0.151]$} \\
\hline Adjusted $R^{2}$ & 0.853 & & 0.857 & \\
\hline Log-likelihood ratio & -634.698 & & -629.725 & \\
\hline Likelihood ratio test & \multicolumn{4}{|l|}{$9.95^{* * *}$} \\
\hline Lagrange multiplier test & \multicolumn{4}{|l|}{$21.87^{* * *}$} \\
\hline Moran's $I$ test & \multicolumn{4}{|l|}{$5.36^{* * *}$} \\
\hline Wald test & \multicolumn{4}{|l|}{$104.66^{* * *}$} \\
\hline
\end{tabular}

Note: ${ }^{*} p<0.1,{ }^{* *} p<0.05,{ }^{* * *} p<0.01$. The bootstrap confidence interval is based on the bias-corrected and accelerated $(\mathrm{BCa})$ method, with a level of confidence of $1-a=0.95$.

Regional Statistics, Vol. 7. No. 2. 2017: 3-34; DOI: 10.15196/RS070205 
The first column reports the estimation of the gravity model $(\varrho=0)$, along with the statistical significance and associated bootstrap confidence intervals. The second column displays the results obtained using the SAR model $(\varrho \neq 0)$. The gravity model is estimated by ordinary least squares (OLS), whilst the SAR model is estimated by using the method of maximum likelihood with a numerical Hessian approach to compute the confidence intervals and associated t-statistics (LeSage and Pace, 2008)..$^{12}$ Both the models explain approximately $86 \%$ of the total variation of domestic flows, and the coefficients associated with the explanatory variables are sensibly the same in the two specifications. ${ }^{13}$ However, the SAR parameter $\varrho$ of the SAR model is statistically significant, which suggests the existence of spatial spillover effects among the regions of destination in Spain. The domestic tourism of a given region benefits from the domestic tourism in its neighbouring regions. More precisely, the trips in a given region of destination increase by almost $0.1 \%$ if the number of inbound trips in its neighbours increases by $1 \%$. This result shows that spatial dependence matters and should be taken into account when modelling domestic demand for tourism. ${ }^{14}$ This also implies that the gravity model would suffer from a problem of misspecification as it omits certain significant spatial effects. This finding is also confirmed by the results of the likelihood ratio test and Lagrange multiplier test reported at the bottom of Table 4: the null hypothesis of no spatial effects is clearly rejected with a $p<0.01$. The residuals of the non-spatial gravity model were also tested for spatial autocorrelation using Moran's $I$ and significant amounts of positive spatial autocorrelation were statistically detected.

In what follows, we will thus only comment on the results based on the SAR model. As shown in Table 5, column 2, most of the explanatory variables are statistically significant and have the expected sign. Distance and relative prices are both negatively associated with inter-regional tourist flows. Conversely, the GDP per capita of the region of destination and origin, population of the region of origin, number of airports both at destination and origin, quality of the beaches, and the cultural, recreational, and natural attractiveness of the regions of destination have a positive and significant influence on the number of inbound trips. Islands benefit from more domestic tourism than mainland Spanish regions, whilst the opposite is found for autonomous cities. Finally, the GPD per capita and size of the population are also both positively associated with intra-regional tourism.

Table 6 reports the total, direct, and indirect effects of each of the explanatory variables included in equation (2), as well as their corresponding statistical signifi-

12 The OLS estimation in the case of the SAR model produces biased, inconsistent, and no-efficient estimates (Dall'Erba-Le Gallo 2008).

${ }^{13}$ The bootstrapping confidence intervals overlapping implies that we cannot reject the null hypothesis that the estimates are statistically equal.

${ }^{14}$ This finding is also corroborated by the value of Moran's $I$ statistic test computed on tourism flows. Moran's $I$ test rejects the null hypothesis of absence of spatial autocorrelation in the dependent variable $(p<0.01)$.

Regional Statistics, Vol. 7. No. 2. 2017: 3-34; DOI: 10.15196/RS070205 
cance derived from the bootstrap procedure. According to these estimates, we can assess the impact of changes in the characteristics of the regions of origin, relative prices, accessibility, and characteristics of the regions of destination on the domestic tourism flows to Spain.

Table 6

\section{Direct, indirect and total impact estimates based on SAR model estimates}

\begin{tabular}{|c|c|c|c|}
\hline Variable & Total impact & Direct impact & Indirect impact \\
\hline \multicolumn{4}{|c|}{ Inter-regional tourism } \\
\hline \multicolumn{4}{|l|}{ Region of destination } \\
\hline GDP per capita & $1.267 * *$ & $1.153^{* * *}$ & 0.114 \\
\hline Blue Flag beaches & $0.006^{*}$ & $0.005^{* * *}$ & $0.001 *$ \\
\hline Museums & $0.012^{*}$ & $0.011 *$ & 0.001 \\
\hline Theme parks & $0.167 * * *$ & $0.152^{* * *}$ & $0.015^{* *}$ \\
\hline Natural parks & $0.618^{* * *}$ & $0.562^{* * *}$ & $0.056^{*}$ \\
\hline Airports & $0.188^{* *}$ & $0.171^{* *}$ & 0.017 \\
\hline Island & $1.295^{* *}$ & $1.178^{* *}$ & 0.117 \\
\hline Autonomous city & $-7.980^{* * *}$ & $-7.261 * * *$ & $-0.719 * * *$ \\
\hline \multicolumn{4}{|l|}{ Region of origin } \\
\hline GDP per capita & $1.200 * * *$ & $1.092 * * *$ & $0.108^{* *}$ \\
\hline Population & $0.744^{* * *}$ & $0.677 * * *$ & $0.067^{*}$ \\
\hline Airports & $0.256 * *$ & $0.233^{* * *}$ & 0.023 \\
\hline Island & 0.109 & 0.099 & 0.010 \\
\hline Autonomous city & -0.221 & -0.201 & -0.020 \\
\hline \multicolumn{4}{|l|}{ Bilateral } \\
\hline Regional prices & $-4.343^{* * *}$ & $-3.952 * * *$ & $-0.391 * * *$ \\
\hline Geographical distance & $-0.003^{* * *}$ & $-0.003 * * *$ & $-0.0002^{* * *}$ \\
\hline \multicolumn{4}{|c|}{ Intra-regional tourism } \\
\hline Log(GDP per capita) & $2.569^{* * *}$ & $2.337 * * *$ & $0.231 * *$ \\
\hline Log(Population) & $1.229 * * *$ & $1.118^{* * *}$ & $0.111^{* *}$ \\
\hline Island & $1.508^{* * *}$ & $1.373 * *$ & $0.136^{* * *}$ \\
\hline Autonomous city & $-11.965^{* * *}$ & $-10.887^{* * *}$ & $-1.078^{* * *}$ \\
\hline
\end{tabular}

Note. ${ }^{*} p<0.1,{ }^{* *} p<0.05,{ }^{* * *} p<0.01$. The $p$-values were empirically estimated by using the bootstrap technique, and Kernel method was employed to estimate the empirical probability density function.

\section{Characteristics of the regions of origin}

The total effect of the GDP per capita in the region of origin, when it comes to explaining inter-regional tourism, is highly significant and equal to 1.20. It implies that, should the residents' income increase by $1 \%$, then the number of inter-regional

Regional Statistics, Vol. 7. No. 2. 2017: 3-34; DOI: 10.15196/RS070205 
trips would increase by $1.20 \%$. Given that the bootstrapped confidence interval associated with this elasticity is $[0.39,2.02]$, the income unitary elasticity assumption cannot be rejected. This finding corroborates the elasticities reported by other authors. De la Mata and Llano-Verduras (2012) and Guardia-Gálvez et al. (2014) report estimated income elasticities equal to approximately $1(0.90)$ and less than 2 (1.8), respectively. In the case of Italy, Marrocu and Paci (2013) found an elasticity income for inter-regional tourism equal to nearly 1 (0.92). The decomposition of the total effect into direct and indirect effects suggests that if the income of the residents in the region of origin increases by $1 \%$, then the number of trips to the region of destination increases by $1.092 \%$ (direct effect), and by $0.108 \%$ in its neighbouring regions (indirect effect). The income elasticity is significantly higher in the case of intra-regional tourism (2.57 versus 1.20). This finding is also in line with Paci and Marrocu (2013) who report estimated income elasticities of 2.13 and 0.92 for intraand inter-regional domestic tourism in Italy, respectively.

Similar to Guardia-Gálvez et al. (2014), we find that the population size in the region of origin is positively associated with inter-regional tourist flows. If the population in the region increases by $1 \%$, then the number of trips to this region will rise by $0.74 \%$. Contrarily to Guardia-Gálvez et al. (2014), the elasticity is significantly less than 1.15

\section{Relative prices}

The estimated price elasticity of the demand for inter-regional tourism amounts to 4.34, which implies that the demand for domestic tourism in Spain is highly elastic. The direct and indirect effects are equal to -3.95 and -0.39 , respectively. GuardiaGálvez et al. (2014) report a price elasticity for inter-regional tourism that is marginally lower, ranging between -3.76 and -3.91 , depending of the method of estimation. However, note that this may be owing to the fact that the authors only take into account the direct effects, ignoring the spillover effects.

\section{Accessibility}

The distance between the region of origin and destination is a factor commonly included in the models of international and inter-regional domestic tourism (Marrocu and Paci, 2013). Our findings reveal that each additional kilometre separating the origin from the destination regions reduces the number of inter-regional tourist trips by $0.003 \%$. Our estimate supports previous studies that consider distance as a proxy for the physical, temporal, and monetary cost of travelling (Guardia-Gálvez et

\footnotetext{
15 The bootstrap confidence interval at 95\% estimated for the population income was [0.51, 0.98], which does not include the value 1 . Therefore, the null hypothesis that the population elasticity is equal to 1 can be rejected at the $5 \%$ level of significance.
}

Regional Statistics, Vol. 7. No. 2. 2017: 3-34; DOI: 10.15196/RS070205 
al. 2014, De la Mata and Llano-Verduras 2012, Marrocu and Paci, 2013).16 The second accessibility variable included in the model, that is the number of airports in the province, which is along these lines, is also a significant pull and push factor for inter-regional domestic tourism. ${ }^{17}$

\section{Characteristics of the regions of destination}

If the GDP per capita in the region of destination increases by $1 \%$, the number of inbound trips in the region increases by $1.15 \%$ (direct effect) and by $0.11 \%$ in its neighbouring regions (indirect effect). However, the spatial spillovers are not significantly different from zero. As the GDP per capita should act as a proxy for the quality of public services (e.g. health care, public transport, infrastructures, or security) and social institutions (e.g. law enforcement, less corruption, or more polite and friendly residents), this result underlines the importance of the economic development in the region of destination as a significant pull factor of domestic tourism.

The variables associated with the cultural (number of museums), recreational (number of theme parks), beaches' quality (number of Blue Flag beaches) and natural attractiveness (number of natural parks) of the regions of destination have a positive and significant effect on the number of inter-regional tourist trips. Considered in total, the direct and indirect effects of all these factors are statistically significant, except for the indirect effect of the variable that approximates cultural attractiveness. These results are perfectly in line with the findings of Marrocu and Paci (2013). However, note that the significant effect of recreational activities that we observe for Spain contrasts with the results of Stracqualursi and Agati (2017) who report no association of this variable with domestic demand in Italy.

The effect of insularity on tourist flows is a source of controversy in the existing literature on the determinants of domestic tourism in Spain. De la Mata and LlanoVerduras (2012) who find a negative effect for the inflows of the islands, argue that this is caused by the larger costs of transportation incurred when travelling to those regions and by the islands' focus on foreign rather than national tourism flows. Conversely, for Guardia-Gálvez et al. (2014), the condition of insularity does not have any negative effect on the flows of domestic tourists and this is due to the gradual reduction of air travel costs. In contrast, our results suggest that islands benefit from $1.18 \%$ more tourist trips than the mainland regions. Similarly, the insularity is also positively associated with domestic intra-regional trips. The residents of the island regions tend to travel more within their region than those of the mainland regions.

\footnotetext{
${ }^{16}$ However, note that some authors, such as Baxter (1979), argue that longer distances could exert a positive effect owing to the satisfaction associated with travelling long distances.

${ }^{17}$ Most of the domestic trips made in Spain in the year 2016 had cars as the main mean of transport. Nevertheless, as Paci and Marrocu (2013) point out, the degree of accessibility of the regions by car is already taken into account with the geographical distance in kilometres between each pair of regions.
}

Regional Statistics, Vol. 7. No. 2. 2017: 3-34; DOI: 10.15196/RS070205 


\section{Robustness and sensitivity analysis}

In this section, we discuss the sensitivity and robustness of our results to check that the main findings of our study are not driven by the model specification. More specifically, we check if our results are sensitive to the most important modelling assumptions assumed in our study: the choice of the SAR model and the queen contiguity matrix as spatial weights matrix.

First, different econometric specifications could have been used to model the spatial interaction effects between regions. Gibbons and Overman (2012) criticise the SAR and favour the spatial lags of X (SLX) model, which consists of augmenting the gravity model with the spatial lags of the explanatory variables. One of the reasons behind Gibbons and Overman (2012)'s preference for the SLX specification is owing to the so-called 'reflection problem' associated with the estimation of an SAR model; that is, the fact that $\varrho$ reflects changes in the observed and unobserved characteristics of the neighbouring regions and as such does not provide any causal information on the effect of the outcome value of the neighbouring regions. The choice of the SAR model in our study was largely driven by the existing empirical evidence on modelling domestic tourism flows based on the O-D approach. Both Marrocu and Paci (2013) and De la Mata and Llano-Verduras (2012) rely on this linear spatial econometric model, and hence for comparison purposes, we opted for the SAR specification. In Table 7, we report the results obtained when two alternative spatial models are estimated: the spatial error (SE) model and the SLX model. A simple comparison appears to indicate that our estimates are not sensitive to the choice of the spatial model. The selection of alternative modelling specifications does not cause significant divergences with respect to our results. In fact, according to the bootstrap analysis, the null hypothesis of equal parameters of the models is not rejected at the $10 \%$ level of significance. The only exception is found for the variable 'Island at destination'. In this case, we can infer that the parameter of the SAR model is significantly higher than the parameters of the SE and SLX models. However, for the latter models, the estimates reflect that the parameters associated with the variable 'Island at destination' were not statistically significant.

Additionally, the most important variables to explain domestic tourism flows in Spain were statistically significant in the gravity and SAR models, as well as in the SE and SLX models. To be more precise, for all models, the variables price, distance, GDP per capita, and population in the region of origin were statistically significant to explain tourism flows between regions (inter-regional tourism). In the case of intra-regional tourism, the variables GDP per capita and population were significant in the four estimated models. It is worth noting that the SE term in the SE models is statistically significant, but in the SLX model, none of the lag explanatory variables were significant.

Regional Statistics, Vol. 7. No. 2. 2017: 3-34; DOI: 10.15196/RS070205 
Table 7

Econometric estimates of the SE and SLX models

\begin{tabular}{|c|c|c|c|c|}
\hline \multirow{2}{*}{ Variable } & \multicolumn{2}{|c|}{ SE model } & \multicolumn{2}{|c|}{ SLX model } \\
\hline & Point estimate & Confidence interval & Point estimate & Confidence interval \\
\hline \multicolumn{5}{|c|}{ Inter-regional tourism } \\
\hline \multicolumn{5}{|l|}{ Region of destination } \\
\hline GDP per capita & 0.707 & {$[-0.242,1.358]$} & $1.681^{* *}$ & {$[-0.269,3.873]$} \\
\hline Blue Flag beaches & $0.003^{*}$ & {$[0.001,0.007]$} & 0.005 & {$[-0.003,0.016]$} \\
\hline Museums & 0.008 & {$[-0.001,0.020]$} & 0.001 & {$[-0.003,0.016]$} \\
\hline Theme parks & $0.140^{* * *}$ & {$[0.099,0.199]$} & 0.089 & {$[-0.057,0.216]$} \\
\hline Natural parks & $0.414 * *$ & {$[0.185,0.757]$} & 0.525 & {$[-0.151,1.271]$} \\
\hline Airports & $0.218^{* * *}$ & {$[0.086,0.345]$} & $0.287^{*}$ & {$[0.074,0.528]$} \\
\hline Island & 0.183 & {$[-0.277,0.933]$} & -0.706 & {$[-2.588,1.104]$} \\
\hline Autonomous city & $-6.863^{* * *}$ & {$[-8.040,-5.630]$} & $-8.566^{* * *}$ & {$[-9.938,-6.902]$} \\
\hline \multicolumn{5}{|l|}{ Region of origin } \\
\hline GDP per capita & $1.243^{* * *}$ & {$[0.536,1.937]$} & $1.155^{* * *}$ & {$[0.308,1.851]$} \\
\hline Population & $0.712^{* * *}$ & {$[0.540,0.937]$} & $0.759 * * *$ & {$[0.548,0.978]$} \\
\hline Airports & $0.296^{* * *}$ & {$[0.147,0.448]$} & $0.287 * *$ & {$[0.074,0.528]$} \\
\hline Island & -0.107 & {$[-0.662,0.579]$} & 0.119 & {$[-0.543,0.969]$} \\
\hline Autonomous city & -0.056 & {$[-0.953,0.930]$} & -0.286 & {$[-1.197,0.759]$} \\
\hline \multicolumn{5}{|l|}{ Bilateral } \\
\hline Relative prices & $-3.069 * *$ & {$[-5.068,-0.48]$} & $-4.953 * *$ & {$[-9.159,-0.636]$} \\
\hline Geographical distance & $-0.003^{* * *}$ & {$[-0.004,-0.002]$} & $-0.003^{* * *}$ & {$[-0.004,-0.002]$} \\
\hline \multicolumn{5}{|c|}{ Intra-regional tourism } \\
\hline GDP per capita & $1.878^{* * *}$ & {$[0.647,2.773]$} & $2.838^{* * *}$ & {$[1.064,5.404]$} \\
\hline Population & $1.273^{* * *}$ & {$[0.500,1.909]$} & $1.197 * * *$ & {$[0.532,1.764]$} \\
\hline Island & 0.721 & {$[-0.050,1.932]$} & 0.379 & {$[-30.971,20.955]$} \\
\hline Autonomous city & $-10.606^{* * *}$ & {$[-13.130,-8.760]$} & $-10.668^{* * *}$ & {$[-12.875,-8.643]$} \\
\hline \multicolumn{5}{|l|}{ Spatial lag variable } \\
\hline GDP per capita & & - & -0.137 & {$[-1.645,5.048]$} \\
\hline Prices & & - & 0.060 & {$[-9.817,3.731]$} \\
\hline Blue Flag beaches & & - & 0.004 & {$[-0.006,0.016]$} \\
\hline Museums & & - & -0.014 & {$[-0.083,0.044]$} \\
\hline Theme parks & & - & 0.050 & {$[-0.089,0.189]$} \\
\hline Natural parks & & - & 1.003 & {$[-0.338,2.741]$} \\
\hline $\mathbf{W}$ error & $0.784 * * *$ & {$[0.537,1.250]$} & & - \\
\hline Adjusted $R^{2}$ & & 0.87 & & 0.85 \\
\hline Log-likelihood ratio & -60 & 5.5316 & -63 & 0.2894 \\
\hline
\end{tabular}

Note: ${ }^{*} p<0.1,{ }^{* *} p<0.05,{ }^{* * *} p<0.01$. The bootstrap confidence interval is based on the BCa method, with a level of confidence of $1-a=0.95$.

Regional Statistics, Vol. 7. No. 2. 2017: 3-34; DOI: 10.15196/RS070205 
Second, as a priori, we do not know the form of the spatial interactions taking place between regions; as such, the choice of the spatial weights matrix is not obvious (Partridge et al. 2012, Vega and Elhorst 2015). To capture the spillover effects, we have used as exogenous pre-specified weighting matrix, the queen contiguityweighting matrix. In this case, the regions are considered as neighbours if they share a common border. The contiguity matrix is one of the oldest and most frequently used weighting matrices in empirical applications (Anselin 1988, Abreu et al. 2004). Moreover, the most recent literature focused on analysing domestic tourism flows from an O-D approach has used this type of weighting matrix (see the studies of Marrocu-Paci 2013, De la Mata-Llano-Verduras 2012).

Other weighting schemes could have been used, such as those based on distance and binary distance matrices; but the effect of geographical distance between two regions is already controlled in our model through the inclusion of the variable distance. ${ }^{18}$ In our opinion, the contiguity matrix used in our study appears to be the most appropriate to describe and capture the spatial effects and neighbouring interactions that exist in the domestic demand for tourism in Spain. However, in order to be sure that our results are not sensitive to the choice of the spatial matrix, we have re-estimated equation (2) whilst considering two different alternative specifications for the weighting matrix. The first one is a standard radial distance matrix that considers neighbours to those regions whose distance is less or equal to 300 kilometres. The second one is a binary distance matrix as defined and used in Dall'Erba and Le Gallo (2008). This matrix is another radial distance matrix that takes into account the inverse of the squared distance between regions, and the lower quartile of the great circle distance distribution is used as the cutting value. In Table 8, we report the estimates of equation (2) when these two alternative spatial weights' matrices are employed. The estimates of the main explanatory variables appear to be relatively robust. Considering the case of inter-regional tourism, the estimates are stable in terms of magnitude, sign, and statistical significance for the variables distance, prices, GDP per capita at origin, population, and theme parks and airports at both origin and destination. In the case of intra-regional tourism, this stability is observed for the variables GDP per capita, population, and autonomous city.

18 The simultaneous inclusion of the variable distance and a weighting matrix based on distances causes distorting effects in the significance of the SAR coefficient $(\varrho)$. More specifically, we have estimated the SAR model defined in equation (2) using an inverse distance weighting matrix. In this case, $\varrho$ was not statistically significant. We obtained a similar result when an inverse quadratic distance matrix was established. However, $\varrho$ becomes significant when the variable distance is omitted. These results are not presented here to save space, but they are available upon request.

Regional Statistics, Vol. 7. No. 2. 2017: 3-34; DOI: 10.15196/RS070205 
Sensitivity of the estimated SAR model in different spatial weighting schemes

\begin{tabular}{|c|c|c|c|}
\hline \multirow[b]{2}{*}{ Variable } & \multirow[b]{2}{*}{ Contiguity matrix } & \multicolumn{2}{|c|}{ Radial distance weights matrix } \\
\hline & & $\begin{array}{c}\text { Bandwidth } \\
300 \text { kilometres }\end{array}$ & $\begin{array}{c}\text { As explained by } \\
\text { Dall'Erba and Le Gallo } \\
\text { (2008) }\end{array}$ \\
\hline \multicolumn{4}{|c|}{ Inter-regional tourism } \\
\hline \multicolumn{4}{|l|}{ Region of destination } \\
\hline GDP per capita & $1.151^{* *}$ & 0.530 & 0.746 \\
\hline Blue Flag beaches & $0.005^{* *}$ & $0.007 * * *$ & 0.001 \\
\hline Museums & $0.011^{*}$ & 0.007 & 0.001 \\
\hline Theme parks & $0.151^{* * *}$ & $0.125^{* * *}$ & $0.185^{* * *}$ \\
\hline Natural parks & $0.561 * * *$ & $0.482^{* * *}$ & $0.293^{*}$ \\
\hline Airports & $0.171 * *$ & $0.276^{* * *}$ & $0.481 * * *$ \\
\hline Island & $1.176^{* *}$ & 0.671 & $-0.794^{*}$ \\
\hline Autonomous city & $-7.246^{* * *}$ & $-6.510^{* * *}$ & $-6.292^{* * *}$ \\
\hline \multicolumn{4}{|l|}{ Region of origin } \\
\hline GDP per capita & $1.090 * * *$ & $1.056^{* * *}$ & 0.665 \\
\hline Population & $0.676^{* * *}$ & $0.680^{* * *} *$ & $0.492 * * *$ \\
\hline Airports & $0.232^{* * *}$ & $0.219 * * *$ & $0.148^{* *}$ \\
\hline Island & 0.099 & 0.103 & 0.021 \\
\hline Autonomous city & -0.201 & -0.141 & 0.169 \\
\hline \multicolumn{4}{|l|}{ Bilateral } \\
\hline Relative prices & $-3.944 * * *$ & $-2.584^{*}$ & $-2.624^{* *}$ \\
\hline Geographical distance & $-0.003^{* * *}$ & $-0.003^{* * *}$ & $-0.002^{* * *}$ \\
\hline \multicolumn{4}{|c|}{ Intra-regional tourism } \\
\hline GDP per capita & $2.333 * * *$ & $1.667 * *$ & $1.491 * *$ \\
\hline Population & $1.116^{* * *}$ & $1.150^{* * *}$ & $0.922 * *$ \\
\hline Island & 1.370 & 1.258 & 1.801 \\
\hline Autonomous city & $-10.866^{* * *}$ & $-10.082^{* * *}$ & $-10.369 * * *$ \\
\hline $\mathbf{W} \cdot Y$ & $0.096^{* * *}$ & $0.127 * * *$ & $0.404^{* * *}$ \\
\hline Adjusted $R^{2}$ & 0.857 & 0.855 & 0.870 \\
\hline Log-likelihood ratio & -629.725 & -632.104 & -617.978 \\
\hline
\end{tabular}

Note: ${ }^{*} \mathrm{p}<0.1,{ }^{* *} \mathrm{p}<0.05,{ }^{* * *} \mathrm{p}<0.01$.

Whilst our results are robust to alternative spatial econometric models and spatial weight matrices, we should be diligent before providing a causal interpretation to our results. Indeed, the SAR and SLX specifications will be biased if there are some omitted variables correlated with both tourism flows and the explanatory

Regional Statistics, Vol. 7. No. 2. 2017: 3-34; DOI: 10.15196/RS070205 
variables included in equation (2). In other words, these spatial econometric models provide consistent estimates if and only if the explanatory variables of equation (2) are exogenous. Whilst some of the characteristics of the origin and destination regions, such as the geographical characteristics are clearly predetermined, other variables, namely, relative prices and GDP per capita are likely to be endogenous. Tackling this potential endogeneity issue would require the usage of natural experiments to provide exogenous variation in the endogenous variables, which is beyond the scope of this paper (Gibbons-Overman 2012).

\section{Conclusions}

Domestic demand for tourism is extremely important for the economy of Spain in terms of economic growth and employment. However, despite its economic importance, the number of studies dedicated to studying the determinants of domestic tourism flows in Spain is still very limited. Thus, there is a growing need to update and expand our knowledge on this topic in order to help policy-makers and managers of the tourism industry to design and implement policies and strategies that promote the competitiveness and profitability of this sector. The present study contributes to fill the existing information gap by first describing the domestic tourist flows in Spain for the year 2016, and second, by identifying the most influencing factors of domestic tourism.

The description of domestic tourism was based on the construction of an O-D matrix, which compiles the number of tourist trips that the residents of a specific region made to another region (inter-regional tourism) or within their own region (intra-regional tourism). In general, most of the inter-regional trips are concentrated in the destination regions of Castilla-León, Andalusia, Valencia, and Castilla-La Mancha. On the other hand, the residents of Madrid, Catalonia, and País Vasco have the highest propensity to visit other regions. Considering that these regions are the richest in Spain, this result suggests that income could play a determinant role to explain inter-regional tourism.

The O-D matrix also allows us to calculate the inter-regional coefficients of tourist attraction. The analysis of these coefficients shows that there is a clear neighbourhood effect among regions; that is, neighbouring regions are more attractive than those located farther away. Second, the level of attractiveness of a region also depends on the distance, population, and economic size of the regions of origin. Regarding intra-regional tourism, the analysis of the O-D matrix reveals that residents of Andalusia and Catalonia are the ones who travel the most within their respective regions.

The second step of analysis aimed at explaining such flows. To this end, a SAR model based on an O-D approach was used to identify the most influencing factors of domestic tourism in Spain. The estimation of an SAR model allows us to

Regional Statistics, Vol. 7. No. 2. 2017: 3-34; DOI: 10.15196/RS070205 
quantify the total, direct, and indirect (spillover) effects. The main results, contributions, and political recommendations derived from the econometric analysis are summarised as follows:

- There is a significant spatial spillover effect among the regions of destination in Spain. The domestic tourist inbounds of a region benefits from the tourism received by its neighbouring regions. This finding is important from an academic point of view owing to two inter-related reasons. The first one is that spatial dependence matters and plays an important role in determining tourist flows. The second reason is that tourism researchers must include spatial effects to model domestic tourism demand. The omission of the spatial effect implies that the commonly used gravity model is not well specified, and hence produces biased estimates.

- The income elasticity of demand for inter-regional domestic tourism is equal to 1 , which implies that the domestic tourism increases or decreases in the same proportion as the income of the residents. In the case of intra-regional tourism, this elasticity is higher (2.57). These estimates are relevant for national and regional policy-makers as they can be used for forecasting the demand for domestic tourism. In this regard, according to the estimates provided by this study and the predictions of the European Commission concerning the Spanish economic growth, the inter-regional domestic tourism in Spain is expected to grow at the rates of $2.8 \%$ in 2017 and $2.4 \%$ in $2018 .{ }^{19}$ Furthermore, intraregional tourism should increase by 7.2 and $6.17 \%$, respectively, in 2017 and 2018.

- The demand for interregional tourism is highly elastic (-4.34). The demand strongly reacts if the level of relative prices rises in the region of destination. In other words, domestic tourists are very price sensitive, which is also indicative of a strong competition among regions for attracting domestic tourism.

- Our results show that distance, which approximates the effect of physical, temporal, and monetary travelling cost, is negatively related to domestic tourism. According to our estimate, the number of tourist trips is reduced by $0.003 \%$ for each kilometre separating the regions of origin and destination.

- The level of wealth in the region of destination has a positive and significant effect on inter-regional tourist flows. The cultural, recreational, and natural characteristics of the regions are important factors of tourist attraction. Our results suggest that political authorities must preserve the quality of the beaches and extend the cultural offer of the regions. Similarly, our study empirically supports the importance of theme parks, and above all, natural parks as driving factors of domestic tourism.

${ }^{19}$ The European Commission foresees that the Spanish economy will grow at 2.8\% in 2017 and $2.4 \%$ in 2018 . This information can be obtained from the webpage: https://ec.europa.eu/info/business-economyeuro/economic-performance-and-forecasts/economic-performance-country/spain/economic-forecast-spain_en.

Regional Statistics, Vol. 7. No. 2. 2017: 3-34; DOI: 10.15196/RS070205 
- Despite the fact that most of the domestic trips are made by car, our results reveal that the number of airports in a region has a positive and significant effect on regional inbound and outbound tourism. Enhancing the importance of airports and facilitating flight connections among regions should contribute to promote domestic tourism.

- The characteristic of insularity is a pull factor for domestic tourism. On the contrary, the autonomous cities of Ceuta and Melilla benefit from less domestic tourism from the other regions of Spain, presumably owing to bad or expensive transport connections.

Our results are robust to different assumptions on the modelling specifications, and provide modest but new and clear evidence of the most relevant push and pull factors of domestic tourism. However, further research is needed to even better characterise and understand the factors that drive the demand for domestic tourism in Spain.

\section{Acknowledgement}

Nicola Pontarollo is greatly acknowledged for providing useful insights on the preliminary version of the paper. The scientific output expressed does not imply a policy position of the European Commission. Neither the European Commission nor any person acting on behalf of the Commission is responsible for the use, which might be made of this publication.

\section{REFERENCES}

Abreu, M.-De Groot, H. L.F.-Florax, R. J. G. M. (2004): Space and Growth: A Survey of Empirical Evidence and Methods Tinbergen Institute Discussion Paper No. 04-129/3.

Álvarez-DíAz, M.-GuPTA, R. (2016): Forecasting the US Consumer Price Index: Does Nonlinearity Matter? Applied Economics 48 (46): 4462-4475. https://doi.org/ 10.1080/00036846.2016.1158922

Álvarez-DíAZ, M.-GonZÁleZ-GómeZ, M.-Otero-GirÁldez, M. S. (2016): La Modelización de la Demanda de Turismo de Economías Emergentes: El caso de la Llegada de Turistas Rusos a España Cuadernos de Economía/Spanish Journal of Economics and Finance 39 (110): 112-125. https://doi.org/10.1016/ j.cesjef.2015.10.001

ANSELIn L. (1988): Spatial Econometrics: Methods and Models Kluwer, Dordrecht.

BaXter, M. J. (1979): The Interpretation of the Distance and Attractiveness Components in Models of Recreational Trips Geographical Analysis 11 (3): 311-315. https://doi.org/10.1111/j.1538-4632.1979.tb00697.x

Bo, Z.-BI, Y.-Hengyun, L.-HAILIN, Q. (2017): The spillover effect of attractions: Evidence from Eastern China Tourism Economics 23 (4): 731-743. https://doi.org/10.5367/te.2016.0541

Regional Statistics, Vol. 7. No. 2. 2017: 3-34; DOI: 10.15196/RS070205 
Cuadrado Roura, J. R.-López Morales, J. M. (2014): El turismo, motor del crecimiento y de la recuperación de la economía española Revista de Estudios Turísticos 200: 19-38.

DALl'ERBA, S.-LE GALLO, J. (2008): Regional convergence and the impact of structural funds over 1989-1999: a spatial econometric analysis Papers in Regional Science 87 (2): 219-244. https://doi.org/10.1111/j.1435-5957.2008.00184.x

De la MatA, T.-Llano-Verduras, C. (2012): Spatial pattern and domestic tourism: An econometric analysis using inter-regional monetary flows by type of journey $\mathrm{Pa}$ pers in Regional Science 91 (2): 437-470. https://doi.org/10.1111/j.14355957.2011.00376.x

DomíngueZ-PÉREZ, M. (2016): Domestic tourism in Uruguay: a matrix approach PasosRevista de Turismo y Patrimonio Cultural 14 (4): 811-825. https://doi.org/ 10.25145/j.pasos.2016.14.053

EXCELTUR (2017): Valoración turística empresarial de 2016 y perspectivas para 2017 No. 59, Enero.

Ferson, W.-NALlareddy, S.-XIE, B. (2013): The "out-of-sample" performance of long run risk models Journal of Financial Economics 107 (3): 537-556. https://doi.org/10.1016/j.jfineco.2012.09.006

GibBOns, S.-Overman, H. G. (2012): Mostly pointless spatial econometrics? Journal of Regional Science, 52 (2): 172-191. https://doi.org/10.1111/j.14679787.2012.00760.x

Griffith, D. A.-Jones, K. G. (1980): Explorations into the relationship between spatial structure and spatial interaction Environment and Planning A 12 (2): 187-201. https://doi.org/10.1068/a120187

Guardia-GÁlvez, T.-Muro Romero, J.-Such DevesA, M. J. (2014): Measuring and analyzing domestic tourism: the importance of an origin and destination matrix Tourism Economics 20 (3): 451-472. https://doi.org/10.5367/te.2013.0286

INE (2017): Notas de Prensa: Encuesta de Turismo de Residentes (ETR/FAMILITUR) Cuarto trimestre de 2016 y año 2016 Instituto Nacional de Estadística, Madrid.

LACAIXA (2017): Monthly Report, MRO6 - Economic and Financial Market Outlook No. 413, Barcelona.

LESAGE, J. P.-PACE, R. K. (2008): Spatial econometric modelling of origin-destination flows Journal of Regional Science 48 (5): 941-967. https://doi.org/10.1111/j.14679787.2008.00573.x

LESAGE, J. P.-PACE, R. K. (2009): Introduction to Spatial Econometrics CRC, Boca Raton.

MARrocu, E.-PACI, R. (2013): Different tourists to different destinations. Evidence from spatial interaction models Tourism Management 39: 71-83. https://doi.org/10.1016/j.tourman.2012.10.009

Medina-Muñoz, D. R.-MedinA-Muñoz, R. D.-GutiérReZ-PÉrez, F. J. (2016): The impacts of tourism on poverty alleviation: an integrated research framework Journal of Sustainable Tourism 24 (2): 270-298. https://doi.org/10.1080/ 09669582.2015.1049611

Morley, C.-Rosselló, J.-SANTANA-Gallego, M. (2014): Gravity models for tourism demand: theory and use Annals of Tourism Research 48: 1-10. https://doi.org/10.1016/j.annals.2014.05.008

Regional Statistics, Vol. 7. No. 2. 2017: 3-34; DOI: 10.15196/RS070205 
Partridge, M. D.-Boarnet, M.-Brakman, S.-Ottaviano, G. (2012): Introduction: whither spatial econometrics? Journal of Regional Science 52 (2): 167-171. https://doi.org/10.1111/j.1467-9787.2012.00767.x

STRACQUALURSI, L.-AGATI, P. (2017): Domestic tourism in Italy: a beta regression model WSEAS Transactions on Mathematics 16: 69-73.

UNWTO (2010): Manual on tourism and poverty alleviation - Practical steps for destinations World Tourism Organization and the Netherlands Development Organization, Madrid.

VEGA, S. H.-ELHORST, J. P. (2015): The SLX model Journal of Regional Science 55 (3): 339-363. https://doi.org/10.1111/jors.12188

WTTC (2017): The economic impact of travel \& tourism: travel \& tourism economic impact for Spain 2017 World Travel \& Tourism Council, London.

YANG, Y.-FIK, T. (2014): Spatial effects in regional tourism growth Annals of Tourism Research 46: 144-162. https://doi.org/10.1016/j.annals.2014.03.007

YANG, Y.-WONG, K. K. (2012): A spatial econometric approach to model spillover effects in tourism flows Journal of Travel Research 51: 768-778. https://doi.org/ $10.1177 / 0047287512437855$ 